\title{
Entrepreneurship Competence Model for Supporting Learners Development at All Educational Levels
}

\author{
Urve Venesaar $^{1, *}$, Elina Malleus ${ }^{2}\left(\mathbb{D}\right.$, Grete Arro $^{2}$ and Martin Toding ${ }^{1}$ \\ 1 School of Business and Governanvce, Tallinn University of Technology, Ehitajate Rd. 5, 19086 Tallinn, Estonia; \\ martin.toding@taltech.ee \\ 2 School of Educational Sciences, Tallinn University, Narva Rd. 25, 10120 Tallinn, Estonia; \\ elina.malleus@tlu.ee (E.M.); grete.arro@tlu.ee (G.A.) \\ * Correspondence: urve.venesaar@taltech.ee
}

Citation: Venesaar, Urve, Elina Malleus, Grete Arro, and Martin Toding. 2022. Entrepreneurship Competence Model for Supporting Learners Development at All Educational Levels. Administrative Sciences 12: 2. https://doi.org/ 10.3390/admsci12010002

Received: 21 September 2021 Accepted: 13 December 2021 Published: 24 December 2021

Publisher's Note: MDPI stays neutral with regard to jurisdictional claims in published maps and institutional affiliations.

Copyright: (C) 2021 by the authors. Licensee MDPI, Basel, Switzerland. This article is an open access article distributed under the terms and conditions of the Creative Commons Attribution (CC BY) license (https:// creativecommons.org/licenses/by/ $4.0 /)$.

\begin{abstract}
The development of entrepreneurship competence considering a broad view of entrepreneurship requires a systematic approach to determine the validated content of learning and methodological basis for supporting learners' entrepreneurial attitudes and behaviour. There is still relatively little research in this area at all levels of education. Addressing entrepreneurship competence as key competence of lifelong learning allows to broaden the understanding and describe the development of different aspects of entrepreneurship competence through meaningful and supportive interactions in the learning environment. This will allow a better understanding of how to support entrepreneurship competence in various courses and age groups. In this article, a framework of entrepreneurship competence called the Comprehensive Entrepreneurship Competence Model (CECM) is proposed. The development of an entrepreneurship competence model relies on the theory of systems thinking. The CECM model focuses on the developmental perspective (fundamental processes of human development) that is not emphasised in other models. The article also suggests how to support the development of entrepreneurship competence systematically at all levels of education through embedding entrepreneurship competence into the curricula, study programmes of different subjects and overall learning processes.
\end{abstract}

Keywords: entrepreneurship competence; competence model; sub-competencies; personal development; designing a teaching model; learning process; all educational levels

\section{Introduction}

Entrepreneurship competence describes the set of knowledge, skills, beliefs and motivational aspects that help individuals cope more efficiently with the increasing globalisation, uncertainty and complexity of the world (Gibb 2002a, 2002b; Lackéus 2015). Entrepreneurship is considered a key competence of lifelong learning, which is essential for all citizens in a knowledge-based society (European Commission 2018), and for increasing the potential of every learner to shape their well-being in the future (OECD 2018, see also OECD 2019). Therefore, the role of educational institutions at all levels is to support the development of entrepreneurship competence to help individuals perform better in an environment not only as entrepreneurs but also as employees and in everyday activities (e.g., Blenker et al. 2011, 2012). Even if the goal of entrepreneurship as key competence of life-long learning is well described in different documents, it does not mean that changes in competencies apply automatically to every classroom. To understand how to support the development of a competence, it should be systematically described what it consists of. We suggest first, that entrepreneurship competence is an emerging phenomenon-that is, the sub-competencies and their relationships determine the overall state of the key competence. Second, some aspects of entrepreneurship competence are more hidden (like growth mindset) than others but still affected by the environment; thus, we need to have a theoretical knowledge of the salient and non-salient aspects of the psyche related to entrepreneurship competence. 
Third, one needs to understand how these sub-competencies develop and how to support their development.

Significant progress has been made towards a better understanding of the development of entrepreneurship competencies (e.g., Baker and Nelson 2005; Lans et al. 2008; Neck and Greene 2011; Man et al. 2002; Morris et al. 2013) by providing different frameworks for the classification of competencies. However, there is little empirical evidence of their practical implementation (Lackéus 2015). Entrepreneurship competence models have been developed in the EU, the UK, the Nordic countries and the US (Bacigalupo et al. 2016; Gibb 2008; Rasmussen and Fritzmer 2016; Rasmussen et al. 2015; U.S. Department of Labor 2019). These models describe what skills are included in entrepreneurship competence. They focus less on how these skills develop and more on what the skills, knowledge and attitudes are based on (e.g., hierarchical structure), making them less transferable to different learning contexts (e.g., elementary schools, students who do not see themselves as entrepreneurs). Creating a model that includes sub-competencies that are empirically proven as potentially developable in all students may be beneficial for educators to better understand the possibilities of developing study programs by choosing relevant teaching models and creating a learner-centred learning environment in the classroom.

It can be seen that the approach to teaching and learning entrepreneurship has also shifted towards the acknowledgement of a broader view of the topic that emphasises entrepreneurship as a way of thinking and acting (e.g., Neck and Greene 2011; Kirby and Ibrahim 2011) and extends the application of entrepreneurial learning to different disciplines. In entrepreneurship, when relying on the process of identifying and exploiting opportunities (Shane and Venkataraman 2000) to realise new value creation, success greatly depends on personal factors, that is, on individuals' key ${ }^{1}$ competencies and on being an entrepreneurial (enterprising) person (Draycott and Rae 2011; European Commission 2006).

In entrepreneurship education, the focus is mainly on the use of business opportunities and new venture creation (e.g., Jones and Matlay 2011; Lackéus 2015). Thus, the learners are mainly acquiring the knowledge and skills needed to identify and exploit opportunities, and there is a lack of support for personal development. Similarly, students in other disciplines (e.g., engineering or IT) typically acquire academic and technical skills but lack other employability skills, also known as work readiness skills (Heijke et al. 2003). These include self-reliance, self-discipline, the ability to solve problems (Falconer and Pettigrew 2003), motivation, teamwork, leadership and communication, numeracy and IT skills (e.g., Stewart and Knowles 2000; Moore and Morton 2017; O'Neil 2014). These skills are necessary for continuous personal and professional development, active citizenship and employability in a knowledge society (Nägele and Stalder 2017; UK Commission for Employment and Skills 2009, p. 9). The "skills gap" concept presents a challenge for curriculum design of how to help learners best to achieve these key skills and to bridge the gap between the learning (university) and application (workplace) settings (Jackson 2013; Nabi 2003; Sarasvathy and Venkataraman 2011).

Entrepreneurship competence should be progressively developed at all educational levels (including the lower grades) to achieve better results. Understanding how one becomes an expert in coping with opportunities and challenges throughout life in different contexts needs better knowledge of how human abilities overall change in their interaction with the environment. For example, we cannot just assume that a person learns by themselves to solve complex problems when exposed to situations where these problems arise. We need to explicitly support the development of effective strategies that help to solve different situations. This means an entrepreneurship competence model should consider learners' developmental specifics and the principles of how our psychological properties function to better explain what being an enterprising person means and thus better support the development of entrepreneurship competence. This is a fundamental principle of the proposed entrepreneurship competence model and to some extent, the main difference when comparing it to other competence models (Bacigalupo et al. 2016; Gibb 2008; Rasmussen and Fritzmer 2016; Rasmussen et al. 2015; U.S. Department of Labor 2019). 
In considering entrepreneurship a key competence for lifelong learning (European Commission 2018), it is important to note how we understand the development of individuals' entrepreneurship competence and the learning process in parallel with the development of professional skills, including entrepreneurship. It may be expected that when individuals participate in the entrepreneurship (education/training) process (i.e., entrepreneurial/business opportunity centred teaching and learning) and the focus is on acquiring a specific set of entrepreneurial knowledge and skills, then all the necessary key competencies are acquired automatically (Garnefski and Kraaij 2014; Pittaway et al. 2010; Rae 2003). Similarly, studies about self-regulated learning (i.e., learning to learn skills) show that teachers often believe that such competencies develop alongside the teaching of the subject and do not require explicit teaching. Contrarily, many studies investigating the development of self-regulated learning show that students need specific guidance and support for the development process to be purposeful (Lawson et al. 2019). One study shows that merely transferring the learning process to the actual workplace does not automatically lead to the development of key competencies and that specific instruction is necessary (Billett 2002) to facilitate learning when theory and practice are combined (Reynolds et al. 2012). Moreover, the focus should be on supporting the deep and variable learning process to achieve long-lasting and flexible changes in knowledge or skills compared to surface learning where only improvements in performance can be documented (for an overview, see Bjork et al. 2013). Considering the important role of individuals in identifying and exploiting opportunities, the development of individuals' competencies in the areas of self-management, creative thinking and social skills in addition to professional knowledge and skills should be an intrinsic part of learning entrepreneurship. This is also important in the learning processes of all other professions.

To contribute to the research on the development of entrepreneurship competence in entrepreneurship education and other domains, it is important to answer two questions: "What does entrepreneurship competence incorporate?" and "How can the development of entrepreneurship competence be supported (teaching/learning)?", complementing the recent research on what and how questions (e.g., Lans et al. 2018; Henry 2020; Baggen et al. 2021). Broadening the content of entrepreneurship competence in relation to cognitive and developmental processes creates a basis for more systematic development of entrepreneurship education and for embedding the development of entrepreneurship competence as a key competence of life-long learning in both general and subject-specific study programs. When an entrepreneurship competence model shows what should be the focus of learning, then the question of how helps to determine the most beneficial teaching strategy to support deep learning and acquire specific knowledge, skills and attitudes. It is important to pay attention to teaching as a complex system encompassing teachers, students, the teaching context, students' learning activities and the outcome (e.g., Biggs 1993, 1996; Fayolle et al. 2006).

Thus, the purpose of this article is to introduce a framework of entrepreneurship competence called the Comprehensive Entrepreneurship Competence Model (CECM) developed within the framework of the Estonian entrepreneurship education program ("Systemic Development of Entrepreneurship and Entrepreneurship Education at All Educational Levels") supported by the Estonian Ministry of Education and Research (2016). The objectives of the proposed CECM are: (1) to offer a set of competencies (and their interactions/relationships) that help understand the behaviour of entrepreneurial (enterprising) people in changing situations (in more specific business-related situations but also in everyday management situations) and (2) to create a basis for the development of educational interventions (entrepreneurship programs and study assignments in various other courses) where skill development is more explicitly supported.

The entrepreneurship competence model helps to solve two problems: (a) to support the development of creative and enterprising people and (b) to contribute to the development of potential entrepreneurs through entrepreneurship education. The present article contributes to a better understanding of the content and characteristics of entrepreneurship 
competence and its sub-competencies based on the proposed CECM. It also describes the theoretical basis of combining different parts of the CECM and the methodological basis for the systematic development of entrepreneurship education and entrepreneurship competence at all educational levels based on the CECM. Relying on systems thinking theory (e.g., Arnold and Wade 2015), the article explains the systematic approach of the research in different levels, including (1) a validated set of interrelated sub-competencies forming a comprehensive content of the competence model (CECM) created to carry out a specific activity; (2) contribution to the systemic development of entrepreneurship education at all educational levels including the design of teaching as a complex system and an instructional guided deep learning process to support changes in learners' subcompetencies. Thus, this is a conceptual article and acts as a theoretical and methodological guide for those involved in education (e.g., education authorities, curriculum developers, teachers/lecturers and learners).

The remainder of the article proceeds as follows. First, a methodology and the process of the development of a comprehensive entrepreneurship competence model are shortly described. Second, the basis and main principles of creating a comprehensive competence model are presented, which is followed by the description of the comprehensive entrepreneurship competence model (CECM). This is followed by a detailed description of the sub-competencies of CECM in four competence areas and separately by each single subcompetency. Third, the explanation on how to apply CECM in practice to better understand the possibilities of supporting the development of entrepreneurship competence in different contexts, that is, in entrepreneurship education and in general and subject-specific courses. This part consists also of the systematic development of entrepreneurship competence at all educational levels and designing the teaching system to support the development of entrepreneurship competence and the guidelines for organising the learning process for supporting the changes in entrepreneurship competence. Finally, the ways to systematically support the development of learners' entrepreneurship competence at all educational levels are focusing on "what" and "how" the development of entrepreneurship competence can be supported. At the end of the article, the contribution of the article, the limitations and future research are explained.

\section{Methodology of the Development of Entrepreneurship Competence Model}

The construction of the model that describes a set of entrepreneurship competencies needed for the systematic development of entrepreneurship education at all educational levels was started in 2015 within the framework of the Estonian entrepreneurship education program ('Systemic Development of Entrepreneurship and Entrepreneurship Education at All Educational Levels') supported by the Estonian Ministry of Education and Research (2016). The first purpose has been to describe and justify the range of competencies needed for the modernisation of education and in supporting the development of entrepreneurship competence of learners (European Commission 2006; Lackéus 2015) for being successful in their studies, at the labour market and in their everyday activities.

When exploring and justifying the set of competencies according to the purpose addressed, we started from desk research with a goal of bringing together the theories of entrepreneurship, but also educational psychology that helps to better understand one's development and behaviour through making sense of motivational, emotional and cognitive processes. At first, we relied on the notion of the entrepreneurship process of discovering and exploiting opportunities (Shane 2003) in environments where these processes occur and in considering the relationship between two important components, the individual and the opportunities. Here, it is considered that the success of discovering and exploiting opportunities as a specialised entrepreneurship sub-competence greatly depends on personal (including psychological) aspects (i.e., key/generic competencies) of the individual(s) involved in the entrepreneurship process (Shane 2003) and on how skills are acquired in this process. 
The definitions and descriptions of sub-competencies have been much discussed in different working groups among researchers, teachers from different educational levels and other specialists, specifically, how to best adopt the theoretical concepts for different levels of education. In this process, the sub-competencies and the learning outcomes were described for each educational level starting from the first level of education until the doctoral study level. Derived from the theoretical sources and work with descriptions of sub-competencies at all educational levels, the first draft of the competence model was created with four fields of sub-competencies, including self-management, creative thinking, managing social situations and acting upon opportunities. The sub-competencies were described in terms of essential knowledge, skills and attitudes of an individual that are essential for value creation during the implementation of ideas, for the development of the entrepreneurial mindset of learners and for efficiently coping with work and everyday life.

In elaborating and explaining the range of necessary competencies in the comprehensive entrepreneurship competence model (CECM), we have relied on the theory of systems thinking. According to Meadows (Meadows 2008; referred in Arnold and Wade 2015), systems thinking consists of three kinds of things: elements, interconnections and a function or purpose. In the case of CECM, the elements are the competencies of learners that need to be developed and the purpose is to support the learners' personal and professional development for being successful in their activities as an entrepreneur, employee or in everyday activities. The interconnections refer to reciprocity between the competencies depending on both the entrepreneurship process and principles of human development. These aspects have been assessed also through the self-assessment tool elaborated in 2016 in parallel with the creation of the CECM (Arro et al. 2018). Therefore, one of the tasks in this process has been also to compile the CECM in a way that the sub-competencies of it can be measured. This has made it possible to validate the reciprocity of sub-competencies of CECM (Venesaar et al. 2018).

The CECM is foreseen to consider a broad view of entrepreneurship and the developmental perspective of learners' competencies at all educational levels through embedding entrepreneurship competence into the curricula through general and subject-specific (including entrepreneurship) study programs by supporting the use of deep learning and creating an appropriate learning environment to achieve the expected learning outcomes.

\section{Theoretical Framework for Creating the Model of Entrepreneurship Competence}

\subsection{Main Principles of Creating a Comprehensive Competence Model}

In describing future goals in education, the Organisation for Economic Co-operation and Development (OECD) project The Future of Education and Skills 2030 emphasises the role of specific key competencies that should be better conceptualised and understood in order to develop them at all educational levels. Two key issues are the need to clarify what knowledge, skills, values and attitudes are necessary, and determining how the educational system can best support the development of key competencies. Therefore, competence models must address these issues. Having a comprehensive entrepreneurship competence model to understand how knowledge, skills and attitudes are related and developed and how to systematically support their development in educational settings is critical. Relying on systems theory (e.g., Dori and Sillitto 2017; von Bertalanffy 1968; Ackoff 1981), the comprehensive entrepreneurship competence model should describe the sub-competencies that are interrelated with each other and address the need to be successful in entrepreneurial activities of value creation in different contexts. It is, therefore, necessary to consider several important characteristics of competencies when creating such a model.

First, from a developmental view, entrepreneurship competence can be thought of as hierarchical and integrative-some aspects of it are lower-order, or prerequisite, for the higher-order, more complex set of skills. This idea stems from the knowledge about executive functions, which can be divided also into basic and higher executive functions (Diamond 2013). Thus, in our model, some sub-competencies (e.g., self-management) are considered as more general and fundamental, forming a basis for all other sub-competencies 
(e.g., thinking and social processes). Taking the developmental perspective, we also describe sub-competencies of being in reciprocal relations forming an integrative system. For example, social and cognitive processes can be seen as intertwined (see for overview Jones and Underwood 2017). This means that from one side, cognitive processes (i.e., problem-solving) drive social information processing, thus better cognitive skills act as a foundation for achieving more purposeful social interactions, that is, being the basis for better management of difficult social situations. On the other side, cognitive skills do not develop in a vacuum and social interactions support the development of creative thinking, etc. Moreover, social skills and cognitive skills together work as a tandem supporting purposeful decision-making when acting upon opportunities and ideas. Thus, although we discuss various sub-competencies in entrepreneurship competence, it should be implicitly recognised that they rely on more fundamental processes, and therefore teachers at all levels of education should be aware of the possibilities to support their development. This means that the ability to solve complex and multifaceted tasks is possible only after more basic skills are acquired (Demetriou et al. 2011).

For example, executive functions - an umbrella term for the mental processes necessary when we need to do something intentional, conscious and non-automatic-form a basis for both higher-order thinking skills, such as planning and problem solving, and social competencies, such as cooperation and communication (which all are important aspects in entrepreneurship competence). Executive functions also include working memory, different inhibition processes and cognitive flexibility (Diamond 2013). Working memory refers to holding information in one's mind while processing it. It is crucial in every situation where it is necessary to make sense of information. For example, connecting unrelated bits of information or extracting important aspects from a mass of information requires good working memory, as does problem-solving using conceptual knowledge instead of relying only on how things seem to be at the present moment. Therefore, planning, decision-making, reasoning and creativity would be impossible without working memory. Inhibition refers to being able to regulate one's attention, emotions, behaviour and thoughts and to resist impulses in favour of more appropriate or reasonable behaviour. Having long-term goals or successful relationships or cooperating with others relies on inhibitory processes. Cognitive flexibility, which depends on working memory and inhibition, is the ability to change perspectives (inhibit our predispositional view and activate a new one) and to change our way of thinking about something (also called 'thinking outside the box' $^{\prime}$ ). It is the basis for finding novel ways of solving problems that cannot be solved in a traditional way. Cognitive flexibility also refers to the ability to adjust to changing situations and environments and not rigidly keep to old ways of acting and thinking (Diamond 2013). All three of these basic executive functions seem to be highly relevant in any kind of entrepreneurial activity. For this reason, basic executive skills must be developed first to be able to acquire entrepreneurship competence, and this helps in understanding the possibility of supporting entrepreneurship competence at every educational level. Executive functions are not a component of the proposed comprehensive competence model but form its foundation and should be considered when planning to teach.

Second, entrepreneurship competence should be described as being dependent on a situation and more or less a supportive environment. Various definitions of competences can be found in the scientific literature that underline the multidimensional nature of the concept of competence and its connection to the context (Mulder et al. 2007). One of the most common definitions of competence is "a comprehensive set of knowledge, skills, and attitudes, the possession of which means successfully coping in the field of the given competence" (e.g., Burgoyne 1989; Stoof 2005; Lackéus 2013; Onstenk 2003). Hence, competence cannot be understood without describing the environment that it should be expressed in and therefore should be considered in relation to the context necessary to function in a particular field.

Third, the understanding of competence has been specified by researchers (e.g., Sánchez 2011; Man et al. 2002) who state that competence can be learned. Several stud- 
ies have investigated how individuals can develop their competencies and have shown that they can be acquired through targeted training (e.g., DeTienne and Chandler 2004). This is important because entrepreneurship competence is sometimes considered a talent or trait, that is, having a strong genetic component (López-Núñez et al. 2020). Even if entrepreneurship competence may have an inherited component, for teachers the understanding that competencies and skills are malleable should be a fundamental principle in teaching. What might make the teaching of competencies confusing is that, contrary to common understanding, competencies do not develop automatically if one is exposed to certain learning situations or programs. Rather, they need to be supported explicitly (e.g., Lawson et al. 2019), and relevant individual differences must be taken into account (Kirschner et al. 2006). In entrepreneurship programs and teaching, educators should also be aware of which sub-competencies should be developed and at what age, particularly as methods of developing some of these sub-competencies are sometimes counter-intuitive. For example, to support motivation people intuitively tend to use motivational mechanisms that are perceived as controlling by students. This actually inhibits autonomous motivation, which is the objective (Reeve 2009; Ryan and Deci 2017).

Fourth, entrepreneurship competence should be described using a holistic competence model that also takes into account competencies that can be characterised as latent constructs, meaning that not all competencies are present in performance (Mulder 2014; referred to in Lans et al. 2018). They are not explicitly distinguished and may not be perceived as a part of entrepreneurial behaviour (e.g., autonomous motivation, regulating emotions, metacognition), but it is important to theoretically distinguish them to support the development of individuals' abilities to achieve better outcomes/performance in entrepreneurship and any other activity. Therefore, they are a justifiable part of a holistic competence model.

Fifth, in creating a holistic model of entrepreneurship competence certain structural principles should be considered. One of the most cited examples in work-related studies is the model by Le Deist and Winterton (2005), who created a holistic framework identifying the combination of competencies necessary for individuals to promote labour mobility. More precisely, the model describes four areas in a multidimensional framework of competence domains that can be conceptually separated, based on a study among managers of small and medium-sized enterprises. These domains are: (1) cognitive (work-related knowledge and the ability to put it to effective use), (2) functional (occupation-specific, the ability to perform a range of work-based tasks effectively to produce outcomes), (3) personal (social/vocational and intrapersonal, the ability to adopt appropriate, observable behaviours in work-related situations) and (4) metacognitive (self-development, communication, creativity, analysis and problem solving) (see also Cheetham and Chivers 1996, 1998; Winterton et al. 2006). In addition, the model in the OECD project identified four domains of key competencies: (1) subject competencies (knowledge, facts, definitions, concepts, systems), (2) methodological competencies (skills, fact-finding, analysis, problem-solving), (3) social competencies (communicating, working interactively, citizenship) and (4) personal competencies (attitudes, values, ethics) (Rychen and Salganik 2003). A general conclusion can be drawn from an overview of these competence models, which is that the subdivisions of the model can be classified as areas of competence consisting of more specialised (e.g., functional, cognitive) or more general competences (e.g., personal, metacognition) (see also Larson et al. 2007). According to Mulder et al. (2009), the holistic approach focuses on developing competence (cognitive, functional and social capabilities) in compliance with the development needs of the field of study, profession or career. Vaidya (2014) refers to the need to comply with two parameters in assessing the quality of competence models: (1) the cognitive, creative and emotional development of the learner is ensured and (2) the implementation of the model focuses on the individual's overall development. Therefore, the competence model that is the basis of learning must offer an overview of competence as a whole and not focus on one or another partial skill or sub-competence (Rasmussen et al. 2015). This can be explained with systems theory (e.g., Dori and Sillitto 2017), according 
to which the competence model consists of a set of connected parts forming a complex whole created to carry out a specific activity. It is, therefore, important to keep in mind that analytically, we should look at the sub-competencies of the competence model separately. However, in the workplace or in other situations, where a certain level of proficiency is necessary, they must be looked at in an integrated way (Tynjälä 2016).

It is also important that integrating competencies with the learner's personal developmental needs and the learning context and activities enhances the successful development of competences both individually and socially. This must be taken into account in education (Mulder 2015). The OECD Learning Framework 2030 presents transformative competencies as a set of specific constructs (e.g., creativity, critical thinking, responsibility, resilience, collaboration) so that teachers and school leaders can better incorporate them into curricula (OECD 2018). The principles that characterise the integrity of the above model have also been taken as a basis for developing the Estonian entrepreneurship competence model in the framework of the national entrepreneurship program (Edu ja Tegu) (Estonian Ministry of Education and Research 2016). In the present article, entrepreneurship competence is meant to encompass a broad approach to entrepreneurship and the context of entrepreneurial activities of people in the process of value creation for others (Vestergaard et al. 2012) in any field: economic, cultural, social. This approach helps in determining the content of entrepreneurship competence and in understanding how this can be developed in educational settings.

\subsection{Creating the Comprehensive Entrepreneurship Competence Model (CECM)}

Based on the definition of entrepreneurship, the concept of entrepreneurship competence can be conceived of as a comprehensive set of knowledge, skills and attitudes that are essential for value creation during the implementation of ideas, for the development of the entrepreneurial mindset of learners and for efficiently coping with work (e.g., entrepreneurs, employees) and everyday life. We rely on the notion of the entrepreneurship process of discovering and exploiting opportunities (Shane 2003) in environments where entrepreneurship processes occur and in considering the relationship between two important components, the individual and the opportunities. The success of discovering and exploiting opportunities as a specialised entrepreneurship sub-competence greatly depends on personal (including psychological) aspects (i.e., key/generic competencies) of the individual(s) involved in the entrepreneurship process (Shane 2003) and on how skills are acquired in this process

Based on the definition of entrepreneurship, acting upon opportunities and ideas includes the higher-order competencies in the hierarchy of entrepreneurship competence (Figure 1). The focus in this area is on business opportunities and the environment where business activities occur. The ability to discover and exploit opportunities is considered an important competence for entrepreneurs to succeed (Ardichvili et al. 2003; Onstenk 2003). While opportunities are not discovered in isolation, this process requires the participant to navigate different aspects of the business environment (e.g., political, economic, social, ecological) at different levels (e.g., local, national, global) and the ability to analyse the environmental impact of value-creating activities (including entrepreneurship) (Rasmussen and Nybye 2013). Therefore, the competence of understanding the environment (e.g., economic, social, political, ecological) is of great importance. In realising ideas in both entrepreneurship and everyday life/society, economic efficiency is important to achieve social goals (although it is by no means the sole factor in achieving those). This is why financial literacy is considered a separate, important competence in the model. This is also justified by the objective of the program to promote the financial literacy of Estonian citizens for 2013-2020: "develop the necessary knowledge, skills, and attitudes necessary for making smart decisions in people's financial matters" (Estonian Ministry of Finance 2013). 


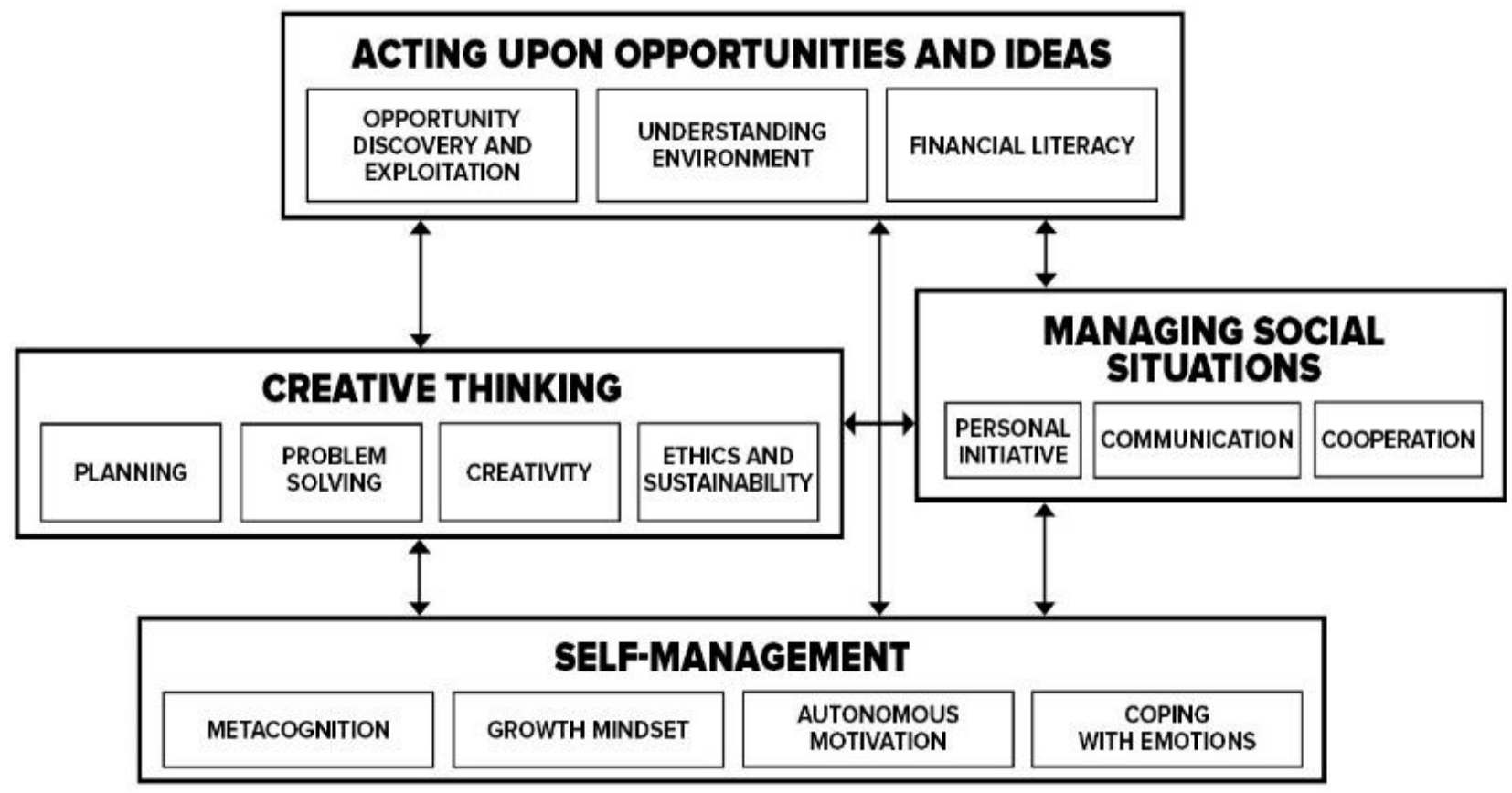

Figure 1. The proposed hierarchical-integrative structure of the entrepreneurship competence model describing reciprocal relations between sub-competencies. Source: created by the authors.

Based on the specifics of entrepreneurship, the entrepreneurship process can only take place if the individual participates in the process. This specificity determines the areas of the competence model that describe the sub-competencies that support individuals ${ }^{\prime}$ enterprising attitudes and behaviour and that are necessary for the successful discovery and exploitation of opportunities. So, to develop specialist sub-competencies (i.e., professional skills) in entrepreneurship, competencies such as creativity, social skills and problemsolving skills are required to facilitate the development and coping abilities of individuals in the labour market and of citizens in society (European Commission 2006; Arevalo et al. 2010; Virtanen and Tynjälä 2019).

The proposed theoretical entrepreneurship competence model consists of four areas of competence that are divided into 14 sub-competencies (Figure 1) that describe the combination of knowledge, skills and beliefs needed to successfully act upon opportunities and ideas to create value in entrepreneurship, employment (employee) and everyday life (as an individual and active citizen).

Those sub-competencies necessary for entrepreneurship, which relate to the initiation and persistence of the activity and to reflection and regulation of one's emotions, thinking and activities, constitute self-management. First, the concept of ability beliefs (mindset) has been described in many contexts, including entrepreneurship and management, indicating that the growth mindset in organisations is related to behaviours bringing long-term success (Keating and Heslin 2015; Murphy and Dweck 2010). Second, the application of selfdetermination theory in the context of organisations has shown that the informed support of motivation mechanisms leads to higher productivity and well-being in both the persistence of the activity and effective management (Deci et al. 2017; see also Baum and Locke 2004). In many cases, the individual's motivation is considered the decisive factor, as it affects the intention to start a business and ensures (or does not) the sustainability of this activity (Carsrud et al. 2017; Audretsch et al. 2008). There are two other sub-competencies in self-management in our model that relate to regulating one's activities, cognition and emotions. Metacognition is a higher-order cognitive process associated with self-regulation that allows for a better evaluation of one's thinking, activity, emotions and relevance to the context. It also helps the entrepreneur to acknowledge different strategies for action, to consider them and to analyse feedback after the operation. More and more studies 
point out the importance of metacognition in the field of entrepreneurship (Haynie et al. $2010,2012)$. The regulation of emotions is considered a sub-competence of self-management because entrepreneurship is typically accompanied by high levels of uncertainty, tension and accountability (Patzelt and Shepherd 2011) and in this case, company survival may be related to the (psychological) survival of the individual. It is impossible to remove the sources of tension from the business environment, but it is possible to develop the skills to support emotional adaptation, coping and well-being. The importance of emotional impact has also been highlighted in finding innovative ideas and solutions (e.g., Jennings et al. 2015) and in assessing emotional reactions to entrepreneurship education (Jones and Underwood 2017; Lackéus 2014).

The field of creative thinking consists of sub-competencies related to thinking skills, such as creativity and problem-solving, which are closely interconnected, but also planning (which can also be considered as one phase of problem-solving) and ethical and sustainable thinking. The need for creative thinking and problem-solving skills is often emphasised in entrepreneurship literature because they help in developing ideas and implementing them in uncertain business environments (e.g., Izquierdo and Deschoolmeester 2010; Sánchez 2011; Basadur and Goldsby 2016). Generating business ideas-an important step in discovering opportunities in the business process-is associated with creativity (Ucbasaran et al. 2008), which is important in using the information collected about business opportunities and in problem-solving (Bird et al. 2012). Problem-solving skills are generally considered the most important of the key competences of the 21st century. The role of problem-solving is also emphasised in the success of operating entrepreneurs (Buttner and Gryskiewicz 1993). The development of these skills is examined in entrepreneurship education (Moore 2007; Martz et al. 2017). The importance of planning skills in the success of a company has been emphasised in empirical studies (Mazzarol et al. 2014; Mitchelmore and Rowley 2013). It has also been pointed out that better planning skills can compensate for the low cognitive ability of entrepreneurs (Escher et al. 2002). The sub-competence of ethical and sustainable thinking is included in the thinking skills area of our model because sustainable and ethical action is based on reasoning skills (e.g., abstract, scientific and systemic thinking) and domain-specific knowledge. The ability to promote sustainable and resilient entrepreneurship that takes into account the actual situation of the world's ecosystems and biodiversity that human civilisation depends upon, that acts ethically and equally vis-à-vis the local and global community and that is profitable at the same time is, in the long run, the most important entrepreneurship competence (OECD 2018). Thus, this sub-competence should act as an evidence-based and deliberate "brake" for unsustainable activities.

The implementation of business ideas requires communicating with team members and creating social networks with external partners and clients in the search for new information, resources and tips (Lans et al. 2015). Therefore, participation in the process of identifying and exploiting opportunities requires the skills to manage social situations. This includes communication and cooperation skills, which are supported by social awareness, managing emotions in communication and self-awareness and self-management in making business decisions in the entrepreneurship process (Baron and Markman 2003). Many authors consider communication skills the most important general competence of an entrepreneur (e.g., Onstenk 2003). The research shows that the success of a company depends on teamwork and networking skills (e.g., Bird 1988). The research also emphasises the need to be proactive, that is, the ability to initiate ideas and act pre-emptively to implement ideas in uncertain business environments (e.g., Sánchez 2011; Izquierdo and Deschoolmeester 2010). Personal initiative and communication and collaboration skills shape the competences necessary to solve social problems.

The above review of the sub-competencies necessary to implement business ideas allows us to answer the question "What competencies (knowledge, skills and attitudes) are needed to successfully act upon opportunities and ideas to create value?". Based on the above, the entrepreneurship competence model developed under the Estonian entrepreneurship program (Edu ja Tegu) can be applied to different levels of education. The 
structure of the entrepreneurship competence model follows the logic of the structure of the comprehensive competence model (e.g., Le Deist and Winterton 2005; OECD 2018) and includes professional competencies of entrepreneurship (i.e., acting upon opportunities and ideas) and competencies supporting enterprising attitudes and behaviour necessary in entrepreneurship, employment and everyday life. It should be considered that all subcompetencies are important and interconnected and can be developed to acquire overall entrepreneurship competence. Their development can be consciously supported and embedded in the learning process of different subjects (European Commission 2012, 2014).

This entrepreneurship competence model has undergone the first empirical test. A survey based on students' self-assessments has highlighted that the relationships between assessed competencies are as expected and has confirmed the results of previous research on different sub-competencies (Venesaar et al. 2018). According to the definition of entrepreneurship (Vestergaard et al. 2012), the sub-competencies can be seen as two different areas/dimensions of focus that determine the concepts of entrepreneurship education in implementing the model: (1) entrepreneurship education as a specialty subject area (i.e., to discover and exploit business ideas) based on a narrow "start-up" view (Neck and Corbett 2018), and (2) entrepreneurship education as a method (Neck and Greene 2011) based on the broader "enterprising" view (Jones and Iredale 2010) of developing the key sub-competences in the areas of self-management, creative thinking and managing social situations. The first dimension is supporting the development of learning entrepreneurship. The second dimension is focused on the integration of learning key sub-competencies in entrepreneurship education and entrepreneurship competence in every other discipline (e.g., math, history, engineering, construction, logistics), thus influencing the outcome of the learning process (Demetriou et al. 2011) and the transition of individuals to the labour market (Grosemans et al. 2017; Mulder 2017).

The implementation of the entrepreneurship competence model helps to guide the planning of curricula and subject syllabuses, which in turn promotes the implementation of new teaching methods and creates a basis for the systematic development of entrepreneurial ability and entrepreneurship education in general, vocational and higher education.

\subsection{Sub-Competencies of the Comprehensive Entrepreneurship Competence Model (CECM) \\ 3.3.1. Acting upon Opportunities}

In the process of acting upon opportunities and ideas, the following professional sub-competencies in entrepreneurship are required: knowledge and skills in discovering and exploiting opportunities and understanding the environment and financial literacy.

Discovering and exploiting business opportunities begins with the market; therefore, market knowledge is necessary to discover opportunities. In the discovery and exploitation process, it is important to look for information, evaluate it and apply it to interactions with the social environment (Kyndt and Baert 2015; Corbett 2005). The process can vary in terms of length, stages and trajectory, depending on the starting position, the goals and the conditions of the process and on the entrepreneurial and professional competences of the team members involved. It is important to understand that in realising business opportunities in entrepreneurial activity, either individually or as a team member, one is directly involved in the value-creation process (individual-opportunity nexus) (Shane and Venkataraman 2000; Shane 2003; Vogel 2017).

Understanding the environment means the ability to navigate the different aspects of the environment (e.g., political, economic, social, technological, ecological) and at different levels (e.g., local, national, global) and thus analyse the impact of the environment on the value-creating (including entrepreneurial) activities (Rasmussen and Nybye 2013). The entrepreneurship environment defines and limits business opportunities and thus affects the rate and size of new enterprises (Bruton et al. 2010). According to a study by Man et al. (2008), entrepreneurs need to consider the outside environment and the company's internal capabilities at the same time to achieve the best performance. Long-term success is ensured by sustainable products and services, production technologies and management 
processes (Lans et al. 2014). It is also important to consider the evidence and influence of the entrepreneurial ecosystem (e.g., Pita et al. 2021) as well as the cultural characteristics of customers, partners and other participants.

Financial literacy means knowing and understanding financial affairs and the associated risks, having the motivation and confidence to make good use of this knowledge in different situations to improve personal and social financial well-being and the ability to enable economic participation (OECD 2016). One also needs basic financial knowledge to plan personal income and expenses, make investment decisions, understand the nature of financial obligations and plan larger purchases (Allgood and Walstad 2016). Financial knowledge and skills also include the ability to understand the content of financial reports and budgets in order to plan future activities (Allgood and Walstad 2016; Grohmann et al. 2018). Although an entrepreneur may delegate financial activities to professionals in the field, he/she needs a basic understanding of financial matters.

\subsubsection{The Area of Self-Management}

Sub-competencies necessary for entrepreneurship that relate to persistence, reflection and regulating one's activities are part of self-management. It also includes metacognition, regulation of emotions, growth mindset and autonomous motivation.

Metacognition refers to the ability to make reasonable and elaborated decisions based on the ability to monitor one's thinking. Metacognition is a higher cognitive process associated with self-regulation that allows for a better evaluation of one's thinking, activity and relevance to the context. It also helps the entrepreneur to acknowledge different strategies for action, to consider them and to analyse the feedback received after the operation. More and more studies point to the importance of metacognition in the field of entrepreneurship (Haynie et al. 2010, 2012) and its relevance in the broader concept of entrepreneurship.

Regulation of emotions refers to the ability to notice, recognise and name one's emotions, to be aware of the different ways of managing emotions and to use these ways according to the situation (e.g., Garnefski and Kraaij 2006). Emotion regulation strategies vary according to how well they support one's adaptation to unpleasant situations. It has been found that cognitive (as opposed to behavioural or social) strategies for regulating emotions, such as finding opportunities to learn from a situation, changing perspective, refocusing on positive or making plans, are most effective (Kraaij et al. 2019; Jones and Underwood 2017). The emotional "cost" of entrepreneurship can be high. This includes a heavy workload, loneliness, a certain level of responsibility and uncertainty in business, all of which can result in stress, burnout, anxiety and fear (e.g., Patzelt and Shepherd 2011; Wei et al. 2015; Fernet et al. 2016; Omrane et al. 2018). If one is unable to cope with their emotions, mental health problems (burnout, mood disorders) may occur, which are likely to inhibit entrepreneurial activity.

Growth mindset. People differ regarding what they think about abilities. Some tend to believe that abilities are unchangeable and permanent (fixed mindset), and others believe that abilities can be developed (growth mindset) (Dweck and Leggett 1988; Dweck and Molden 2017; Haimovitz and Dweck 2016; Yeager and Dweck 2012). There is enough evidence from cognitive and neuropsychology that abilities really are malleable, that is, the growth mindset is in line with the knowledge about learning and development (Thomas et al. 2020). The belief that abilities are malleable is found to be related to behaviours that bring success in learning, such as investing more effort and concentration in learning, trying things out with different strategies, asking for help and curiosity about the reasons for one's mistakes (see, e.g., Blackwell et al. 2007; Dweck 2007; Haimovitz and Dweck 2016). In organisations, it has been found that the growth mindset is related to behaviours that bring long-term success (Keating and Heslin 2015; Murphy and Dweck 2010).

Autonomous motivation means that an action is meaningful and valued by the actor and corresponds to what the person considers important and/or interesting (Deci and Ryan 2000; Deci and Moller 2005). It has been found that this type of motivation is strongly 
affected by the social environment. In organisations, it has been shown that the informed support of autonomous motivation leads to greater productivity and well-being in terms of persistence and effective management (Deci et al. 2017; see also Baum and Locke 2004).

\subsubsection{Creative Thinking}

Under the sub-competencies related to the area of creative thinking skills, we consider creativity, problem-solving and planning skills, which are closely interconnected. We also consider ethical and sustainable thinking.

Creativity can also be considered a characteristic, but in the context of entrepreneurship, it is the process of associating different kinds of information units and assembling them into a novel and functional whole in a specific context. Creativity is a malleable skill (e.g., Barak 2013; Dziedziewicz et al. 2014) that depends on a variety of basic processes, such as working memory (i.e., the ability to focus on multiple pieces of information at the same time) and cognitive flexibility (i.e., the ability to exchange viewpoints and let go of the obvious; see, e.g., Diamond 2013). In addition to these processes, the prerequisites for creativity are conceptual knowledge and the systematic practice of searching for creative solutions.

Problem-solving requires a systematic step-by-step approach to understand and define a problem, to understand the criteria for a good decision, to find ideas to solve a problem, to select and evaluate ideas and to make a plan about how to act (Basadur and Goldsby 2016). The role of problem-solving skills is emphasised as a predictor of opportunity identification competence (e.g., Baggen et al. 2015) and in the success of operating entrepreneurs (Buttner and Gryskiewicz 1993). As a rule, business problems are so-called complex problems-difficult to identify, characterised by ambiguous constraints and multiple solutions and difficult to evaluate with regard to the effectiveness of solution options (Jonassen 2010, 2011). Problem-solving requires time and awareness of one's thinking process and skills.

Planning is a goal-oriented and step-by-step process that requires the ability to think ahead. The prerequisite for successful planning is the ability to monitor and direct the process, the ability to recognise the goal and the steps leading to it and the ability to analyse after every step whether it contributes to the final goal. The latter also means that planning assumes some flexibility in goals and activities, as the situations in entrepreneurship are constantly changing. Planning involves reflection and the organisation of activities to achieve the desired goal (see e.g., Collins and Koechlin 2012; Cowan 2014). It has been pointed out that better planning skills can compensate for other shortcomings of entrepreneurs (Escher et al. 2002).

Ethical and sustainable thinking requires knowledge in relevant areas, awareness of the limitations of one's own knowledge and the understanding of abstract information (compared to tangible or common-sense information), such as the complex relationships between factors that have effects that occur over a period of time or the systematic structure of phenomena (e.g., ecosystem). Ecosystems, climate and cycles of matter (e.g., hydrological or carbon cycles) are continually being changed and disturbed because of current operational strategies (see, e.g., Cohen and Winn 2007; Goel and Joshi 2017; Gao and Bansal 2013). In this perspective, the ability to promote sustainable, ethical and resilient entrepreneurship is becoming essential. Although it is a challenge for educators to support these kinds of thinking skills, there is some evidence of success (Ranney and Clark 2016; Muis et al. 2020).

\subsubsection{Managing Social Situations}

A necessary skillset to manage social situations in entrepreneurship is comprised of personal initiative, communication and collaboration skills.

Personal initiative refers to behaviours related to self-directed, proactive, prospective and lasting work (Frese and Fay 2001). Personal initiative also involves discovering and exploiting opportunities and being receptive to new ideas (DeShon and Gillespie 2005). Gollwitzer and Brandstätter (1997) have found that greater initiative leads to success as an 
entrepreneur and in the development of the enterprise. Personal initiative is strongly linked to other sub-competences of entrepreneurship. For example, a person who takes initiative typically believes in the development of their abilities, is innovative and determined to pursue their goals (Crant 2000). Proactivity in the workplace can be more sustainable when it is driven by autonomous motivation, that is, autonomously regulated proactivity (Strauss and Parker 2014).

Communication skills reflect an individual's ability to cope in different social situations to achieve social goals (Gresham and Elliott 1987). Good communication reflects the ability of an individual to (1) process social information, (2) be tolerant, empathetic and ethical (including being open to dissent, compromise and constructive conflict resolution) and (3) notice and respond appropriately to the reactions of others (Bartram 2005). In the context of entrepreneurship, communication skills are also assessed based on negotiating and presenting skills and considering the expectations and needs of the target group (investors, entrepreneurs, customers, partners, etc.) in preparing one's message and presenting ideas (Bacigalupo et al. 2016). Communication skills not only contribute to good results in relationships but also enhance employee participation (Vorhauser-Smith 2013), which in turn increases the productivity and sustainability of a company.

Cooperation skills refer to a set of skills that help one be collaborative. Cooperation can be defined as a collective effort in which team members want to achieve common goals (Anderson-Butcher et al. 2014; Salas et al. 2008; Tambe 1997). This means that team members have the competencies to accomplish goals and to monitor their ongoing performance as a team, to be aware of responsibilities and to desire to work as a team (Baker et al. 2006). Cooperation also requires understanding the importance of networking and the different forms of cooperation and involving the participants in the value-creation process (Bacigalupo et al. 2016) in order to increase the competitiveness of companies.

The above review of the competencies necessary to act upon opportunities allows us to answer the question "What competences (knowledge, skills and attitudes) are needed to successfully implement ideas and create value through them?". Based on the above, the entrepreneurship competence model developed under the Estonian entrepreneurship education program $(E d u \mathcal{E} T \mathrm{Teg} u)$ includes a description of its structure and the sub-competencies at the individual level that should be taken into account in developing the objectives of entrepreneurship education at different levels of education.

\section{Using Comprehensive Entrepreneurship Competence Model (CECM) in Learning Process}

\subsection{Systematic Development of Entrepreneurship Competence at All Educational Levels}

The principles derived from the model of entrepreneurship competence are applied both in formal and non-formal education (including in refresher training and lifelong learning). The development of entrepreneurship competence as a key competence should be supported in entrepreneurship education as an area of specialisation and also in all other subject areas. Within the framework of the Estonian entrepreneurship program (Edu $\mathcal{E}$ Tegu), the learning outcomes have been described for all target groups and levels of education based on the entrepreneurship competence model introduced (Arro et al. 2018).

The sub-competencies of the entrepreneurship competence model can therefore be integrated into all subjects and/or modules of the curriculum at all levels of education (basic education, upper secondary education, vocational education and higher education) depending on the specific content of subjects/modules and stages of study. For example, in general education, especially up to elementary school (stages I and II of study), the emphasis is particularly on shaping enterprising attitudes and behaviour (i.e., developing sub-competencies related to self-management, creative thinking and social competencies). From primary school (stage III of study), when elective subjects related to entrepreneurship education are added to the national curriculum, the focus of learning shifts; the development of competencies related to the entrepreneurship process and activities becomes more important. The focus and objectives of entrepreneurship education in vocational education 
are consistent with the respective level of general education (stage III of study and level 2 of vocational training and level 4 of upper secondary school and vocational education). In higher education, entrepreneurship education clearly focuses on acting upon opportunities and business ideas, and the objective is to prepare the learners for entrepreneurship and intrapreneurship. However, the competencies relating to the personal development of students supporting their enterprising abilities should also be embedded in the study process, which supports the development of students' competencies to cope better in the labour market (as entrepreneurs or employees) and in society.

Personal competencies are best developed across contexts (see the example of social competence in (Jones and Bouffard 2012) and the example from vocational education in (Mulder 2017)). This means that it is beneficial to integrate competence development into everyday learning and bring in similar topics across different subjects. One of the main characteristics of key competencies is that they can be developed in every study discipline, in contrast to specific competencies (e.g., Heijke et al. 2003). The integration of the development of different sub-competencies in different subjects allows the creation of a system (curriculum) to achieve the expected outcomes of developing enterprising people/graduates.

\subsection{Designing a Teaching System to Support the Development of Entrepreneurship Competence}

It is important to pay attention to teaching as a complex system encompassing teacherstudent interactions in the learning environment and processes to form/construct the outcome (e.g., Biggs 1993; Toutain and Fayolle 2017). Based on Biggs (1999), all components should be constructively aligned so that the learning environment evokes students' deep learning to achieve the intended outcomes (including assessments and impact measures). Here, the outcome-oriented design supports teachers' awareness of what to take into account throughout the whole learning process (including the assessment) and how different factors play crucial roles in students' motivation, competence formation and overall change in understanding the learning content.

This means that when planning a (entrepreneurship) course, the answers to the five specific questions (why, for whom, for which results, what and how) can be addressed for a more systematic design and implementation of teaching programs that support both content knowledge and competence development (Fayolle et al. 2006). The first three questions (why, for whom and for which results) help in understanding and considering the profiles and backgrounds of learners (target group), their learning goals and the outcome for the target group. The outcome in the current task of the development of entrepreneurship competence is seen to have two results: (a) support the development of enterprising people considering a broad view of entrepreneurship and (b) contribute to the more specific concept of new venture and value creation-oriented competence development in entrepreneurship education. Therefore, supporting the development of enterprising people is important to achieve among all learners, that is, in general and subject-specific education, including entrepreneurship education. The question of what expresses the specific content of learning, which is entrepreneurship competence. Entrepreneurship competence can be considered the professional knowledge, skills and attitudes necessary for new venture creation or intrapreneurship, but in a wider context, this represents the key competence of life-long learning in entrepreneurship. The development of key competence in entrepreneurship is suggested as necessary to achieve better academic progress (supported by (Demetriou et al. 2011) with a theory of developing mind) and to ensure the employability of graduates (e.g., Grosemans et al. 2017) and individual wellbeing (OECD 2018).

The specific value of implementing the entrepreneurship competence model in education is connected to embedding the development of learners' key competences (i.e., supporting their personal development) in the curricula and the study processes in addition to the development of their subject-specific (or professional) competence. From here, the question how leads to the creation of learner-centred learning environments and selecting teaching approaches and methods to support the learning process while consid- 
ering learners' profiles and goals in achieving the intended outcomes. This depends on teachers' knowledge, skills and beliefs and their ability to adapt the learning process for deep learning that supports changes in entrepreneurship competence.

\subsection{Learning Process That Supports Changes in Entrepreneurship Competence}

The effective practices that support entrepreneurship competence development are packed into everyday learning processes (e.g., see (Jones and Bouffard 2012) for social competence). Therefore, the development of the entrepreneurship sub-competencies should be supported through different sequenced activities (e.g., specific assignments) and prompts (questions, feedback, overall conversations) in the learning process with a goal to support the overall conceptual development of key competence within a specific area/topic (see Figure 2). This means that principles of the learning process familiar to the conceptual change perspective can be also used to support the development of different sub-competencies of entrepreneurship competence.

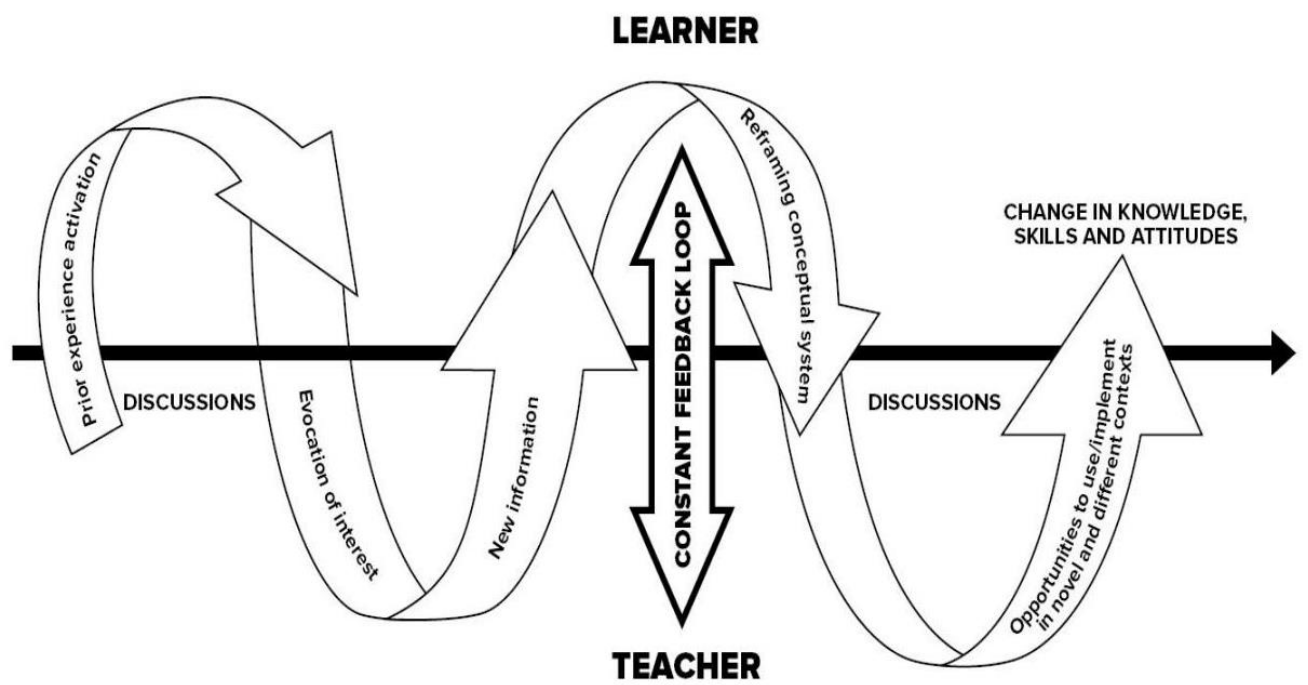

Figure 2. The explanatory model of an instructionally guided learning process. Source: created by the authors based on conceptual change theory (e.g., Vosniadou 2007).

To understand better how the conceptual change perspective applies to entrepreneurship competence support, a creativity sub-competence was chosen to illustrate the possibilities. The development of conceptual understanding of creativity should be supported in a lecture/class using more explicit instructional guidance (Kirschner et al. 2006). The learning process described by using a conceptual change approach focuses on how learners construct and reconstruct their understanding (e.g., Novak 2002; Vosniadou 2007). One important aspect is to make learning transparent and to formulate learning goals together with students that also include competence development, that is, creativity. First, learners' prior knowledge, skills and beliefs related to creativity should be used as building blocks for the development of understanding (Figure 2). Teaching should activate prior knowledge and experience (e.g., remembering situations where creativity was used and self-assessing one's creativity) and new information (e.g., learning about the perspective of creativity as a malleable skill) should be built on it through ongoing discussions offering opportunities to reframe the existing conceptual understanding of creativity (Larraín 2017), sometimes correcting misinterpreted information (e.g., showing that creativity can be developed in all students) and supporting the development of more adaptive beliefs. Focus on prior experience contributes to having a sense of relatedness, and thus students may be more interested in the topics under discussion (evocation of interest; Sinatra 2005). This means that the learning process should evoke and support students' metacognitive processes and thinking about their own learning together with other key competencies and knowledge about the content by paying attention to correcting students' misunderstandings. Better 
awareness of one's learning process supports long-lasting changes in understanding. This means that learners should be constantly encouraged to think about their learning, for example, to think back about how they thought about the same concept (creativity) at the beginning and how they think about it now (Sinatra and Taasoobshirazi 2018). A constant feedback loop should help students to see what they know, what they do not know (e.g., combination of self-assessment and discussions with the teacher) and what they need to learn to move forward. Finally, the learning process will be validated if learners use learnt knowledge, skills and attitudes in novel and different contexts (e.g., real-life situations, such as being an entrepreneur or a worker and adopting everyday citizenship behaviour, but also throughout the overall learning process when other topics are covered).

The described interaction between teacher and learner in the conceptual changeoriented learning process depends on how the other components of the complex teaching system are organised, that is, the design of learning programs and environments considering (1) the adopted definition of entrepreneurship in accordance with the needs and interests of the targeted audience; (2) learners' profiles and developmental specifics (educational level, discipline, age, psychological profile, background and prior experience); (3) pedagogical tools and methods used for teaching (relying on socio-constructivist theory, including experiential learning, learning by doing, problem-based learning and project development); and (4) objectives and an evaluation of outcomes. Thus, the development of entrepreneurship competence can be supported through the learning process, but this does not happen independently of context and school system (e.g., curriculum design, teachers' / lecturers' experiences, possibilities to take part in different projects, etc.). This should be taken into account in every school system where entrepreneurship education is systematically developed.

\subsection{Entrepreneurship Competence Development in Entrepreneurship Education}

In entrepreneurship education programs, the use of the principle of opportunityoriented learning (Rae 2003) is supported (e.g., Steyaert 2007; Man 2007). Considering entrepreneurship a heterogenous and multifaceted phenomenon (Fayolle et al. 2006), entrepreneurship educators have to create supportive learning environments for effective learning using the process of discovery, evaluation and exploitation of opportunities (Shane 2003) to help students acquire both business understanding and competencies for individual self-development. Here, the entrepreneurship education program should be based on clear conceptions at the ontological level by defining both entrepreneurship and education (Fayolle et al. 2006). Thus, the definition of entrepreneurship as the starting point for entrepreneurship education determines both the content and purpose of studies and the teaching methods and assessment (Ernest Samwel Mwasalwiba 2010).

Entrepreneurship education programs are often based on the ideas of experiential learning theories (Kolb 1984) or socio-constructivist learning theories (Biggs 1993; Tynjälä 1999; Vygotsky 1978, 1986). However, the literature on entrepreneurship education suggests that together with learning cognitive skills relating to entrepreneurship, more attention should be paid to learners' personal development (e.g., Lans et al. 2018). As the development of the self cannot occur by itself during practical "learning by doing" activities, instructional guidance is needed (Kirschner et al. 2006). This means that teachers should provide special instructional guidance (see Section 3.2 and Figure 2 above) to promote the development of competencies that support the development of enterprising attitudes and behaviour, for example, competencies in the areas of self-management, creative thinking and managing social situations that do not develop automatically.

In supporting learners' enterprising attitudes and behaviour, decisions have to be made in the entrepreneurship process, at which stage it is most appropriate to pay more attention to the sub-competencies necessary to develop the self. Below is a figure showing the possible links between sub-competencies and the entrepreneurship process (Figure 3). According to the figure, the entrepreneurship process starts with the analysis and selfassessment of learners' personal attitudes and abilities, where it is appropriate to pay 
attention to the students' understanding of their mindset, motivation and attitude towards entrepreneurship and the activation of prior knowledge and skills. Then, at the stage of identifying the client's problem, the focus shifts to the thinking skills, including creativity, problem-solving, planning skills and ethical and sustainable thinking. At the stage of discovering business opportunities, it might be expedient to address in more depth the skills related to the initiation and handling of different types of social situations (e.g., tasks to develop initiative, communication and cooperation skills). This way, each stage of the learning process can be complemented by tasks supporting the development of subcompetencies, which are important to better act in the entrepreneurship process. Learners can test their competencies in the process of developing their business ideas through practical activities, which in turn will gradually increase the level of their entrepreneurship competence as a whole. This way, different aspects of personal development can be addressed at different stages, which influences the ability to regulate oneself in the process of implementing business ideas and allows achieving more reasoned decisions.

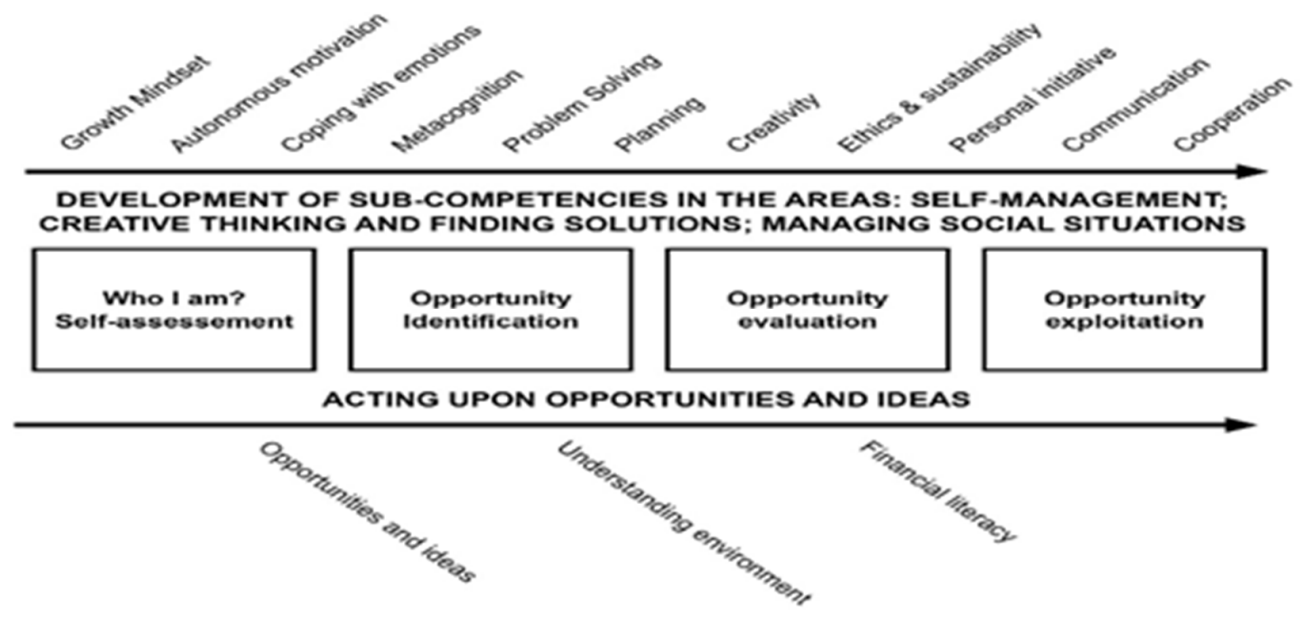

Figure 3. Development of sub-competences of entrepreneurship competence during the different stages of the entrepreneurial process. Source: created by the authors.

The integration of entrepreneurship sub-competencies into the learning process depends on the learning objectives, the focus of the content, the nature of the business process, the skills and choices of teachers and mentors and other factors. However, the example illustrates the general principle of developing a learning process based on the entrepreneurship process and a student-centred learning approach supporting the development of entrepreneurship competence as a whole and every sub-competence separately. However, a more reasoned framework to embed the sub-competencies for learners' personal development into the study process should be based on the results of empirical research in the future.

This approach can be supported by integrating self-assessment for learning into the study process. When, in entrepreneurship education, the entrepreneurship process supports such an approach, embedding the development of entrepreneurship competence into the subject-specific courses requires a different approach, that is, considering the aim and content of the subject-specific course, which can be very different in different specialities.

\subsection{Embedding Entrepreneurship Competence in General and Subject-Specific Courses}

Entrepreneurship competence development can also be integrated into general or specialty subjects where learning is not based on the entrepreneurship process but on other subject content. The main task of teachers and lecturers is to understand what entrepreneurship competence means and to supervise and guide the learning process in a way that enables supporting learners to develop the key competence of entrepreneurship. 
The integration of entrepreneurship competence development into general and subjectspecific course programs at different educational levels can only be done in each subject individually (taking into account the specifics of the subject) and may be done in a different way. The implementation of the entrepreneurship competence model is more effective if the model's sub-competences, especially those that support the development of individuals' enterprising abilities, are integrated systematically and in a coordinated way into all subjects and/or modules of the curriculum. Based on the learning objectives, content, teaching principles and expected learning outcomes of the curricula, it is possible to see opportunities for the development of entrepreneurship as a key competence. For example, subjects in the arts can support the development of creativity, but so can mathematics, as creativity means seeing different solutions to similar problems, and combining different ways of solving a mathematical problem can help one to be more open to various strategies. Mathematics can also support the development of financial knowledge and skills. The other example is connected with the humanities, where, in various situations, the skills to handle social situations can be developed by showing how entrepreneurs think about and describe their struggles.

The entrepreneurship competence model consists of different sub-competencies that can all be integrated into various subjects and developed through the curriculum of educational institutions. For example, physical training lessons are a great context to understand how thinking about one's strategies (metacognition, planning, problem-solving) to perform different exercises can help to achieve better results. Physics lessons can be a place to think about sustained effort and how to motivate oneself (autonomous motivation) if situations become more difficult. Mathematics lessons may offer possibilities to break barriers related to creativity, and after developing the necessary knowledge base, new and different assignments in relation to various goals can be created by students themselves, possibly in pairs or groups ${ }^{2}$.

\section{Discussion}

This article aimed to find ways to systemically support the development of learners' entrepreneurship competence at all educational levels by focusing on answering two questions: "What does entrepreneurship competence incorporate?" and "How can the development of entrepreneurship competence be supported (teach/learn)?" complementing the prior research on what and how questions in entrepreneurship education (e.g., Lans et al. 2018; Henry 2020). To that end, a comprehensive entrepreneurship competence model (CECM) was introduced that shows what the content and focus of learning should be. The question of how helps in choosing the most beneficial teaching strategy through supporting a deeper conceptual change-oriented learning process and achieving a specific set of knowledge, skills and attitudes that can help individuals perform better at work (i.e., as entrepreneurs or employees) and in everyday activities.

The purpose of the CECM developed in the Estonian entrepreneurship program (Edu $j a \mathrm{Teg} u$ ) is to combine a scientifically validated set of knowledge, skills and attitudes that supports the development of entrepreneurship education at all levels of education (Arro et al. 2018). The sub-competencies were chosen and the model (theoretical concept) was developed based on the definition of entrepreneurship as the process of the discovery and exploitation of opportunities and the theoretical and conceptual perceptions developed in fields of science related to entrepreneurship, including (developmental) psychology, education, social psychology, etc. In addition, the model is combined with educational psychology theories that allow a better description of how to support the development of the chosen sub-competencies in the school environment, depending on the level of education. Relying on previous experience in the formation of holistic competence models (e.g., Le Deist and Winterton 2005; Mulder et al. 2009; Rychen and Salganik 2003; Vaidya 2014), all these sub-competencies in the CECM form the key competence of life-long learning in entrepreneurship, which is essential for all citizens in society (European Commission 2006, 2018). Therefore, the creation of CECM is supported by the systems theory (e.g., Dori and 
Sillitto 2017; von Bertalanffy 1968; Ackoff 1981) helping to explain that the model describes a purposeful (meant to carry out entrepreneurial activities) structure of sub-competencies that are interrelated with each other and satisfy individuals' need to be successful in the entrepreneurial activities of value creation in different fields and contexts.

The CECM also shows how different sub-competencies are hierarchical and integrative, where some sub-competencies of it are lower-order and more general (e.g., growth mindset, autonomous motivation, regulating emotions), or prerequisite for the higher order, more complex and specific competencies (e.g., in the areas of creative thinking, managing social situations and acting on opportunities and ideas). All competencies in the model rely on fundamental processes (e.g., executive functions), which can also be divided into basic and higher executive functions (Diamond 2013). This explains the development of the sub-competencies by the level of education, for example, which sub-competencies should be developed and at what age. This helps to clarify the principles that are taken as the basis for the development of individuals' enterprising abilities and entrepreneurship education and that must be followed in planning the integration of the development of enterprising ability as a key competence in the context of different subject-specific learning processes. It is also necessary to consider several important characteristics of competencies (e.g., the relationship with the context, learnability, latency, hierarchy).

This article highlights the developmental side of entrepreneurship competence and explains how the CECM can be integrated into the learning process considering reciprocal relations of sub-competencies. The application of the CECM creates an opportunity for the systematic development of entrepreneurship competence in different ways. That is, it provides a set of competencies necessary for creating the holistic content of the competence model (CECM), and it should be supported at all educational levels and should be embedded in general and subject-specific courses (in different contexts). Hence, it allows more explicit planning possibilities to create a better connection between curricula concerning the development of learners' entrepreneurship competence at different educational levels to increase the employability of graduates.

To support the development of entrepreneurship competence, it is important to pay attention to teaching as a complex system encompassing teachers and students to create a learning environment that evokes students' deep learning (changes in conceptual understanding) to achieve the intended outcomes. This means that the use of a learner-centred teaching approach and real-life (problem-based) active teaching methods are supported and that teaching and assessment need to be aligned to the intended learning outcomes. Here, it is important to underscore that competencies do not develop automatically if one is exposed to certain learning situations or programs; rather, they need to be supported explicitly (e.g., Lawson et al. 2019) and to take into account possible relevant individual differences (Kirschner et al. 2006). Therefore, although the opportunity-oriented teaching model in entrepreneurship education supports the development of enterprising abilities to a certain extent (Pittaway et al. 2010), it is still necessary to pay more attention to learners' personal development by supporting the development of their self-management, creative thinking and ability to manage social situations. This supports learners to be more successful in entrepreneurial activities. This requires understanding how the instructional system can best support the development of key competence of entrepreneurship at different educational levels. This article addressed these questions and proposed a CECM.

A specific explanatory model of the learning process was proposed, as was the creation of a learning process that supports changes in entrepreneurship competence. Here, based on the instructional guiding of deep learning (Kirschner et al. 2006), the authors propose a model of the learning process consisting of different phases (e.g., activating prior knowledge, ongoing discussions and constant feedback; see also (Larraín 2017)) that results in the creation of opportunities to reframe the existing conceptual understanding of the subcompetence. The deep learning process will be validated if students use learnt knowledge, skills and attitudes in novel and different contexts (e.g., real-life situations, such as being an entrepreneur, worker or citizen). The creation of a motivating learning environment (i.e., 
supporting autonomy, competence and relatedness) depends on teachers' knowledge, skills and beliefs and their ability to adapt the learning process for deep learning that supports changes in entrepreneurship competence. Therefore, adopting the relevant instructional support is very important for the development of entrepreneurship competence as a key competence at different levels of education and for the development of the educational system. Here, it is required that all teachers and lecturers must be aware of the content of the model and the opportunities for developing the sub-competences in order to achieve the better performance of individuals in educational settings, at work and as citizens in general.

The entrepreneurship competence model should be seen as being in constant development in accordance with the research and considering the future challenges of social, economic and environmental development. It is important to consider certain restrictions in this model. For example, the choice of competencies in this model was based on the definition of entrepreneurship and the possible competencies supporting the opportunity identification and exploitation and the development of entrepreneurial self (supported by prior research). However, there may be factors that affect the development of entrepreneurship competence not listed in this model. The model also needs to be refined to empirically evaluate its validity and to clarify how the competencies described above affect how one becomes an entrepreneur and acts as an entrepreneur and how one hones one's general entrepreneurial ability in working life (as an employee) and in everyday activities.

\section{Conclusions and Practical Implications}

The article continues with the discussion on the issues raised in the literature on the development of entrepreneurship education considering the broad view to entrepreneurship (e.g., Blenker et al. 2011, 2012; Baggen et al. 2021). Searching for solutions to the questions of "what" and "how" to better support students' personal development and their entrepreneurial mindset together with their specialty studies, this article presents a comprehensive entrepreneurship competence model (CECM) of the key competence of life-long learning in entrepreneurship. The model is relying on the theory of systems thinking of entrepreneurship and sciences related to entrepreneurship (education, psychology) and taking into account the developmental perspective (fundamental processes of human development). Hence, the article includes suggestions on how to support the development of entrepreneurship competence systematically at all levels of education throughout the learning process in different contexts (schools, courses). The main value of the model is to supplement the entrepreneurship education traditional study programs (focusing on acting upon opportunities) with the development of students' self-management, creative thinking and managing social situations and to suggest the integration of the development of entrepreneurship competence to the subject-specific courses. Besides this, in parallel with the creation of the model, the measurement tool was developed, which helped to validate the choice of sub-competencies to the model (Venesaar et al. 2018). For successful integration of entrepreneurship competence into different courses, this article is emphasising on paying attention to teaching as a complex system encompassing teachers and students to create an appropriate learning environment and is proposing a learning process that supports changes in entrepreneurship competence.

The main principles, the basis of creating the comprehensive entrepreneurship competence model and the description of every single sub-competence in the model helps educators to understand the choice of sub-competencies, opens their content and possibilities to use this information when preparing the learning materials for supporting the development of learners' entrepreneurship competence in different contexts (schools, curricula, courses).

Unlike other competence models, the model presented in this article (CECM) shows how different sub-competencies are hierarchical and integrative, taking into account the reciprocal relations of sub-competencies forming an integrative system based on the knowledge about executive functions (Diamond 2013). This helps educators to understand the sub-competencies in CECM being fundamental and a basis for other sub-competencies and 
how sub-competencies of different hierarchical levels are intertwined. Derived from these reciprocal relations of sub-competencies, educators at all educational levels are becoming aware of the possibilities to support the development of different sub-competencies.

The systematic development of entrepreneurship competence at all educational levels explains how entrepreneurship competence can be applied both in formal and non-formal education (e.g., life-long learning), or integrated into all subjects and/or modules of the curriculum of primary schools, secondary and vocational schools and higher education. The model includes sub-competencies that are empirically proven as potentially developable in all students. This is beneficial for educators to better understand the possibilities of developing study programs by choosing relevant teaching models and creating a learner-centred learning environment in the classroom to support students' entrepreneurial attitudes and behaviour.

Designing the teaching system to support the development of entrepreneurship competence emphasises the qualities of teaching as a complex system, which is important to consider when planning the course of entrepreneurship and answering the five specific questions (why, for whom, for which results, what and how), which supports educators for more systematic design and implementation of teaching programs. Acknowledging the design principles of teaching and learning also supports educators of subject-specific courses to embed the development of learners' key competence in entrepreneurship (i.e., personal development) in the curricula and study processes in addition to the development of subject-specific (i.e., professional) competence in practice.

The formation of a learning process that supports changes in entrepreneurship competence is explained based on a practical example of sub-competences from the CECM, which shows an instructional guided deep learning process to explicitly support the development of entrepreneurship sub-competencies being a direct practical guide for educators when coaching students in the classroom.

The main limitation of the research is that it relies on practical experience of piloting the model and self-assessment tool in one country, Estonia. At the same time, the model has been validated for different target groups, that is, students at different educational levels. Considering also that the fundamental sources of the model are based on the theories and research published in international journals, the model and its developmental suggestions are in general applicable in other countries, but the cultural and other differences need to be considered.

The example of the development of entrepreneurship competence in entrepreneurship education and in general and subject-specific courses through the use of self-assessment for learning presents the practical guidelines for educators when planning their study or training programs for different target groups. Finally, the use of CECM as well as suggestions on how to apply entrepreneurship competence and its sub-competencies to practice is contributing to the creation of systematic support of learners' entrepreneurial attitudes and behaviour.

\section{Future Research}

In accordance with the topic and the results of the research of this article, future research should pay attention to the ways of embedding the development of entrepreneurship competence and its sub-competencies co-ordinately into curricula, and study programs of different courses of specialties at different educational levels and countries. Here, it would be beneficial to bridge the research and practice to find scientifically substantiated ways for educators to create the study framework and learning environment that gives all learners a possibility to develop, step-by-step, the sub-competencies of entrepreneurship competence.

To achieve the results explained above, teachers need training for learning a new approach to educating students. They need to learn the content of the entrepreneurship competence model, the essence of each sub-competencies, as well as how to integrate the development of certain sub-competence into the study program of the course and how to develop these within an instructional guided deep learning process, also considering the 
teaching system of the school. For that, the research on the framework of integration, adding the entrepreneurship competence sub-competencies into the curricula and study programs, would help researchers and educators to better understand the process of embedding entrepreneurship as a key competence of lifelong learning into the teaching processes.

Future research should investigate and elaborate on different measurement tools for assessing changes in entrepreneurship competence and its sub-competencies during an intervention, which would help to find the best teaching models.

Research in different cultural contexts could bring out more specific features in the development of entrepreneurship competence content and its application into practice.

Author Contributions: Conceptualisation, U.V., E.M., G.A.; resources, U.V., E.M., G.A., M.T.; writingoriginal draft preparation, U.V., E.M., G.A., M.T.; writing-review and editing, U.V., E.M., G.A., M.T.; visualisation, U.V., E.M., G.A.; coordination, U.V. All authors have read and agreed to the published version of the manuscript.

Funding: This research was funded by the European Social Fund and the Estonian Ministry of Education and Research under the programme "Systematic Development of Entrepreneurship Education on All Levels of Education in Estonia".

Institutional Review Board Statement: Not applicable.

Informed Consent Statement: Not applicable.

Data Availability Statement: Not applicable.

Conflicts of Interest: The authors declare no conflict of interest.

\section{Notes}

1 In different contexts and situations, the term "key competencies" (European Commission 2006, 2018) is also expressed as general/generic, transversal competencies and employability competencies. Key competences are those which all individuals need for personal fulfilment and development, employability, social inclusion, a sustainable lifestyle, a successful life in peaceful societies, health-conscious life management and active citizenship (European Commission 2018).

2 The examples of embedding different sub-competencies into different disciplines are described in https:/ / ettevotlusope.edu.ee/ uldhariduse-valikaine-ja-kursuse-moodul-3-4-astme-oppuritele/ (in Estonian) (accessed on 1 September 2021).

\section{References}

Ackoff, Russell L. 1981. Creating the Corporate Future: Plan or Be Planned for. New York: University of Texas Press.

Allgood, Sam, and William B. Walstad. 2016. The effects of perceived and actual financial literacy on financial behaviors. Economic Inquiry 54: 675-97. [CrossRef]

Anderson-Butcher, Dawn, Anthony J. Amorose, Leeann M. Lower, Allison Riley, Allison Gibson, and Donna Ruch. 2014. The case for the Perceived Social Competence Scale II. Research on Social Work Practice 26: 419-28. [CrossRef]

Ardichvili, Alexander, Richard Cardozo, and Sourav Ray. 2003. A theory of entrepreneurial opportunity identification and development. Journal of Business Venturing 18: 105-23. [CrossRef]

Arevalo, Javier, Sari Pitknen, David Gritten, and Liisa Tahvanainen. 2010. Market-relevant Competencies for Professional Foresters in European Graduate Education. International Forest Review 12: 200-8. [CrossRef]

Arnold, Ross D., and Jon P. Wade. 2015. A Definition of Systems Thinking: A Systems Approach. Procedia Computer Science 44: 669-78. [CrossRef]

Arro, Grete, Juta Jaani, Krista Loogma, Elina Malleus, Eneken Titov, Martin Toding, Marge Täks, and Urve Venesaar. 2018. Ettevõtlikkuse ja Ettevõtlusõppe Süsteemne Arendamine Eestis. Edu ja Tegu Ettevõtlusõppe Programm. Külastatud Aadressil. Available online: https:/ / xn--ettevtluspe-jfbe.ee/wp-content/uploads/2018/12/raamdokument_web_3.pdf (accessed on 1 September 2021).

Bacigalupo, Margherita, Panagiotis Kampylis, Yves Punie, and Godelieve Van den Brande. 2016. EntreComp: The Entrepreneurship Competence Framework. Luxembourg: Publication Office of the European Union.

Baggen, Yvette, Jakob Mainert, Thomas Lans, Harm J. A. Biemans, Samuel Greiff, and Martin Mulder. 2015. Linking complex problem solving to opportunity identification competence within the context of entrepreneurship. International Journal of Lifelong Education 34: 412-29. [CrossRef]

Baggen, Yvette, Thomas Lans, and Judith Gulikers. 2021. Making Entrepreneurship Education Available to All: Design Principles for Educational Programs Stimulating an Entrepreneurial Mindset. Entrepreneurship Education and Pedagogy 2515127420988517. [CrossRef] 
Baker, Ted, and Reed E. Nelson. 2005. Creating Something from Nothing: Resource Construction Through Entrepreneurial Bricolage. Administrative Science Quaterly 50: 329-66. [CrossRef]

Baker, David P., Rachel Day, and Eduardo Salas. 2006. Teamwork as an essential component of high-reliability organizations. Health Services Research 41: 1576-98. [CrossRef]

Barak, Moshe. 2013. Impacts of learning inventive problem-solving principles: Students' transition from systematic searching to heuristic problem solving. Instructional Science 41: 657-79. [CrossRef]

Baron, Robert A., and Gideon D. Markman. 2003. Beyond social capital: The role of entrepreneurs' social competence in their financial success. Journal of Business Venturing 18: 41-60. [CrossRef]

Bartram, Dave. 2005. The great eight competencies: A criterion-centric approach to validation. Journal of Applied Psychology 90: 1185-203. [CrossRef]

Basadur, Min, and Michael Goldsby. 2016. Design-Centered Entrepreneurship. New York and London: Routledge Taylor and Francis Group.

Baum, J. Robert, and Edwin A. Locke. 2004. The relationship of entrepreneurial traits, skill, and motivation to subsequent venture growth. Journal of Applied Psychology 89: 587-98. [CrossRef] [PubMed]

Biggs, John B. 1993. From theory to practice: A cognitive systems approach. Higher Education Research and Development 12: 73-85. [CrossRef]

Biggs, John B. 1996. Enhancing teaching through constructive alignment. Higher Educatio 32: 347-64. [CrossRef]

Biggs, John B. 1999. What the Student Does: Teaching for enhanced learning. Higher Education Research and Development 18: 57-75. [CrossRef]

Billett, Stephen. 2002. Toward a workplace pedagogy: Guidance, participation, and engagement. Adult Education Quarterly 53: 27-43. [CrossRef]

Bird, Barbara. 1988. Implementing entrepreneurial ideas: The case for intention. Academy of Management Review 13: 442-53. [CrossRef]

Bird, Barbara, Leon Schjoedt, and J. Robert Baum. 2012. Entrepreneurs' Behavior: Elucidation and Measurement. Editor's Introduction. Entrepreneurship Theory and Practice 36: 889-913. [CrossRef]

Bjork, Robert A., John Dunlosky, and Nate Kornell. 2013. Self-regulated learning: Beliefs, techniques, and illusions. Annual Review of Psychology 64: 417-44. [CrossRef]

Blackwell, Lisa S., Kali H. Trzesniewski, and Carol Sorich Dweck. 2007. Implicit theories of intelligence predict achievement across an adolescent transition: A longitudinal study and an intervention. Child Development 78: 246-63. [CrossRef] [PubMed]

Blenker, Per, Steffen Korsgaard, Helle Neergaard, and Claus Thrane. 2011. The questions we care about: Paradigms and progressions in EE. Industry and Higher Education 25: 417-27. [CrossRef]

Blenker, Per, Signe Hedeboe Frederiksen, Steffen Korsgaard, Sabine Müller, Helle Neergaard, and Claus Thrane. 2012. Entrepreneurship as everyday practice: Towards a personalized pedagogy of enterprise education. Industry \& Higher Education 26: 417-30. [CrossRef]

Bruton, Garry D., David Ahlstrom, and Han-Lin Li. 2010. Institutional Theory and Entrepreneurship: Where Are We Now and Where Do We Need to Move in the Future? Entrepreneurship Theory and Practice 34: 421-40. [CrossRef]

Burgoyne, John. 1989. Creating the managerial portfolio: Building on competency approaches to management development. Management Learning 20: 56-61. [CrossRef]

Buttner, E. Holly, and Nur Gryskiewicz. 1993. Entrepreneurs' problem-solving styles: An empirical study using the Kirton adaption/innovation theory. Journal of Small Business Management 31: 22-31.

Carsrud, Alan, Malin Brännback, Jennie Elfving, and Kristie Brandt. 2017. Motivations: The entrepreneurial mind and behavior. In Understanding the Entrepreneurial Mind. Edited by Alan L. Carsrud and Malin Brännback. Berlin and Heidelberg: Springer, pp. 141-65.

Cheetham, Graham, and Geoff Chivers. 1996. Towards a holistic model of professional competence. Journal of European Industrial Training 20: 20-30. [CrossRef]

Cheetham, Graham, and Geoff Chivers. 1998. The reflective (and competent) practitioner: A model of professional competence which seeks to harmonise the reflective practitioner and competence-based approaches. Journal of European Industrial Training 22: 267-76. [CrossRef]

Cohen, Boyd, and Monika I. Winn. 2007. Market imperfections, opportunity and sustainable entrepreneurship. Journal of Business Venturing 22: 29-49. [CrossRef]

Collins, Anne, and Etienne Koechlin. 2012. Reasoning, learning, and creativity: Frontal lobe function and human decision-making. PLoS Biology 10: e1001293. [CrossRef]

Corbett, Andrew C. 2005. Experiential learning within the process of opportunity identification and exploitation. Entrepreneurship Theory and Practice 29: 473-91. [CrossRef]

Cowan, Nelson. 2014. Working memory underpins cognitive development, learning, and education. Educational Psychology Review 26: 197-223. [CrossRef] [PubMed]

Crant, J. Michael. 2000. Proactive behavior in organizations. Journal of Management 26: 435-62. [CrossRef]

Deci, Edward L., and Arlen C. Moller. 2005. The concept of competence: A starting place for understanding intrinsic motivation and self-determined extrinsic motivation. In Handbook of Competence and Motivation. Edited by Andrew J. Elliot and Carol S. Dweck. New York: Guilford Press, pp. 579-97. 
Deci, Edward L., and Richard M. Ryan. 2000. The 'what' and 'why' of goal pursuits: Human needs and the self-determination of behavior. Psychological Inquiry 11: 227-68. [CrossRef]

Deci, Edward L., Anja H. Olafsen, and Richard M. Ryan. 2017. Self-Determination Theory in work organizations: The state of a science. Annual Review of Organizational Psychology and Organizational Behavior 4: 19-43. [CrossRef]

Demetriou, Andreas, George Spanoudis, and Antigoni Mouyi. 2011. Educating the Developing Mind: Towards an Overarching Paradigm. Educational Psychology Review 23: 601-63. [CrossRef]

DeShon, Richard P., and Jennifer Z. Gillespie. 2005. A motivated action theory account of goal orientation. Journal of Applied Psychology 90: 1096-127. [CrossRef]

DeTienne, Dawn R., and Gaylen N. Chandler. 2004. Opportunity identification and its role in the entrepreneurial classroom: A pedagogical approach and empirical test. Academy of Management Learning and Education 3: 242-57. [CrossRef]

Diamond, Adele. 2013. Executive functions. Annual Review of Psycholog 64: 135-68. [CrossRef]

Dori, Dov, and Hillary Sillitto. 2017. What is a System? An Ontological Framework. Systems Engineering 20: 207-19. [CrossRef]

Draycott, Matthew, and David Rae. 2011. Enterprise education in schools and the role of competency frameworks. International Journal of Entrepreneurial Behaviour \& Research 17: 127-45.

Dweck, Carol S. 2007. Boosting achievement with messages that motivate. Education Canada 47: 6-10.

Dweck, Carol S., and Ellen L. Leggett. 1988. A social-cognitive approach to motivation and personality. Psychological Review 95: 256-73. [CrossRef]

Dweck, Carol S., and Daniel C. Molden. 2017. Self-theories: Their impact on competence motivation and acquisition. In Handbook of Competence and Motivation. Edited by Andrew J. Elliot and Carol S. Dweck. New York: Guilford Publications, pp. $122-40$.

Dziedziewicz, Dorota, Aleksandra Gajda, and Maciej Karwowski. 2014. Developing children's intercultural competence and creativity. Thinking Skills and Creativity 13: 32-42. [CrossRef]

Escher, Susanne, Rafal Grabarkiewicz, Michael Frese, Gwenda van Steekelenburg, Maartje Lauw, and Christian Friedrich. 2002. The moderator effect of cognitive ability on the relationship between planning strategies and business success of small scale business owners in South Africa: A longitudinal study. Journal of Developmental Entrepreneurship 7: 305-18.

Estonian Ministry of Education and Research. 2016. Entrepreneurship Programme "Systemic Development of Entrepreneurship and Entrepreneurship Education at All Educational Levels. Programme introduction". Tartu: Estonian Ministry of Education and Research. (In Estonian)

Estonian Ministry of Finance. 2013. Eesti Elanike Finantskirjaoskuse Edendamise Programm Aastateks 2013-2020. Tallinn: Estonian Ministry of Finance. (In Estonian)

European Commission. 2006. Key Competences for Lifelong Learning. Recommendation of the Members of the European Parliament and the Council" (2006/962/EC; 18 December). Brussels: Commission of the European Communities.

European Commission. 2012. Rethinking Education: Investing in Skills for Better Socio-Economic Outcomes. Communication from the Commission to the European Parlament, the Council, the European Economic and Social Committee and the Committee of the Regions. Strasbourg. 20.11.2012. COM(2012) 669. Brussels: Commission of the European Communities.

European Commission. 2014. Entrepreneurship Education: A Guide for Educators. Brussels: GHK Consulting Ltd.

European Commission. 2018. Council Recommendation of 22 May 2018 on key competences for life long learning. Official Journal of the European Union 1-13.

Falconer, Stewart, and Malcolm Pettigrew. 2003. Developing added value skills within an academic programme through work-based learning. International Journal of Manpower 24: 48-59. [CrossRef]

Fayolle, Alain, Benoît Gailly, and Narjisse Lassas-Clerc. 2006. Assessing the impact of entrepreneurship education programmes: A new methodology. Journal of European Industrial Training 30: 701-20. [CrossRef]

Fernet, Claude, Sarah-Geneviève Trépanier, Stéphanie Austin, and Julie Levesque-Côté. 2016. Committed, inspiring, and healthy teachers: How do school environment and motivational factors facilitate optimal functioning at career start? Teaching and Teacher Education 59: 481-91. [CrossRef]

Frese, Michael, and Doris Fay. 2001. Personal initiative: An active performance concept for work in the 21st century. Research in Organizational Behavior 23: 133-87. [CrossRef]

Gao, Jijun, and Pratima Bansal. 2013. Instrumental and integrative logics in business sustainability. Journal of Business Ethics 112: 241-55. [CrossRef]

Garnefski, Nadia, and Vivian Kraaij. 2006. Cognitive emotion regulation questionnaire-Development of a short 18-item version (CERQ-short). Personality and Individual Differences 41: 1045-53. [CrossRef]

Garnefski, Nadia, and Vivian Kraaij. 2014. Application of best practices in university entrepreneurship education. Designing a new MBA program. European Journal of Training and Development 38: 231-53. [CrossRef]

Gibb, Allan. 2002a. Creating conducive environments for learning and entrepreneurship. Living with, dealing with, creating and enjoying Uncertainty and Complexity. Industry and Higher Education 16: 135-47. [CrossRef]

Gibb, Allan. 2002b. In pursuit of a new "enterprise" and "entrepreneurship" paradigm for learning: Creative destruction, new values, new ways of doing things and new combination of knowledge. International Journal of Management Reviews 4: 233-69. [CrossRef]

Gibb, Allan. 2008. Entrepreneurship and enterprise education in schools and colleges: Insights from UK practice. International Journal of Entrepreneurship Education 6: 101-44. 
Goel, Manisha, and Bhagwati Prasad Joshi. 2017. Entrepreneurship and Sustainable Development. Journal of Entrepreneurship and Management 6: 43-51.

Gollwitzer, Peter M., and Veronika Brandstätter. 1997. Implementation intentions and effective goal pursuit. Journal of Personality and Social Psychology 73: 186-99. [CrossRef]

Gresham, Frank M., and Stephen N. Elliott. 1987. The relationship between adaptive behaviour and social skills: Issues in definition and assessment. The Journal of Special Education 21: 167-81. [CrossRef]

Grohmann, Antonia, Theres Klühs, and Lukas Menkhoff. 2018. Does financial literacy improve financial inclusion? Cross country evidence. World Development 111: 84-96. [CrossRef]

Grosemans, Ilke, Liesje Coertjens, and Eva Kyndt. 2017. Exploring learning and fit in the transition from higher education to the labour market: A systematic review. Educational Research Review 21: 67-84. [CrossRef]

Haimovitz, Kyla, and Carol S. Dweck. 2016. Parents' views of failure predict children's fixed and growth intelligence mind-sets. Psychological Science 27: 859-69. [CrossRef] [PubMed]

Haynie, J. Michael, Dean Shepherd, Elaine Mosakowski, and P. Christopher Earley. 2010. A situated metacognitive model of the entrepreneurial mindset. Journal of Business Venturing 25: 217-29. [CrossRef]

Haynie, J. Michael, Dean A. Shepherd, and Holger Patzelt. 2012. Cognitive adaptability and an entrepreneurial task: The role of metacognitive ability and feedback. Entrepreneurship Theory and Practic 36: 237-65. [CrossRef]

Heijke, Hans, Christoph Meng, and Catherine Ris. 2003. Fitting to the Job: The Role of Generic and Vocational Competencies in Adjustment and Performance. Maastricht: Research Centre for Education and the Labour Market, Maastricht University. [CrossRef]

Henry, Colette. 2020. Reconceptualizing the role of the future entrepreneurship educator: An exploration of the content challenge. Entrepreneurship \& Regional Development 32: 657-76. [CrossRef]

Izquierdo, Edgar, and Dirk Deschoolmeester. 2010. What Entrepreneurial Competencies Should Be Emphasized in Entrepreneurship and Innovation Education at the Undergraduate Level? Available online: https://d1wqtxts1xzle7.cloudfront. net/30980933/Rencontres_2008_Deschoolmester_Izquierdo_f-with-cover-page-v2.pdf?Expires=1640337773\&Signature= TlsfVw692BK3YyZhtZiZZ8G6lnoiOJVFwaebBbWso84R \{\}zE3xxx2tr1eul1pzjSYso \{\}KPk2prt3539Y-bXvui9M9gfoFqkQ0zEt2 1xN-JZ3-eS-TRcBmH \{ffD5xyAdbMGLiTmsETTSO2cS0nDq676gqMIgjvWP16eWGytp3ODDuuCakyXuAcW7WyVgKf7AQHbMFC2BauGRdUvCiRdfAWhj10EHrqjowFjZNzrNPqNBNE9v518sEwPwTt5udubr2qiMm615PgMzqLAqWLsMDYTZ2 mqUpSUmtEir0ALtrVvFjhE081egc2XyCARcbQ1Xo7qRsUcZKiozmhVxcgHP5Wqw_\&Key-Pair-Id=APKAJLOHF5GGSLRBV4 ZA (accessed on 1 September 2021).

Jackson, Denise. 2013. Business graduate employability where we going wrong. Higher Education Research and Development 32: 776-90. [CrossRef]

Jennings, Jennifer E., Tim Edwards, P. Devereaux Jennings, and Rick Delbridge. 2015. Emotional arousal and entrepreneurial outcomes: Combining qualitative methods to elaborate theory. Journal of Business Venturing 30: 111-30. [CrossRef]

Jonassen, David H. 2010. Learning to Solve Problems: A Handbook for Designing Problem-Solving Learning Environments. New York and London: Routledge.

Jonassen, David H. 2011. Supporting Problem Solving in PBL. Interdisciplinary Journal of Problem-Based Learning 5: 95-119. [CrossRef]

Jones, Stephanie M., and Suzanne M. Bouffard. 2012. Social and emotional learning in schools: From programs to strategies and commentaries. Social Policy Report 26: 1-33. [CrossRef]

Jones, Brian, and Norma Iredale. 2010. Enterprise education as pedagogy. Education + Training 52: 7-19. [CrossRef]

Jones, Colin, and Harry Matlay. 2011. Understanding the heterogenity of entrepreneurship education: Going beyond Gartner. Education + Training 53: 692-703. [CrossRef]

Jones, Sally, and Sarah Underwood. 2017. Understanding students' emotional reactions to entrepreneurship education. A conceptual framework. Education + Training 59: 657-71. [CrossRef]

Keating, Lauren A., and Peter A. Heslin. 2015. The potential role of mindsets in unleashing employee engagement. Human Resource Management Review 25: 329-41. [CrossRef]

Kirby, David A., and Nagwa Ibrahim. 2011. Entrepreneurship education and the creation of an enterprise culture: Provisional results from an experiment in Egypt. International Entrepreneurship Management Journal 7: 181-93. [CrossRef]

Kirschner, Paul, John Sweller, and Richard E. Clark. 2006. Why Minimal Guidance During Instruction Does Not Work: An Analysis of the Failure of Constructivist, Discovery, Problem-Based, Experiential, and Inquiry-Based Teaching. Educational Psychologist 41: 75-86. [CrossRef]

Kolb, David. 1984. Experiential Learning. Englewood Cliffs: Prentice-Hall.

Kraaij, Vivian, Janneke Bik, and Nadia Garnefski. 2019. Cognitive and behavioural coping in people with Chronic fatigue syndrome: An exploratory study searching for intervention targets for depressive symptoms. Journal of Health Psychology 24: 1878-83. [CrossRef] [PubMed]

Kyndt, Eva, and Herman Baert. 2015. Entrepreneurial competencies: Assessment and predictive value for entrepreneurship. Journal of Vocational Behavior 90: 13-25. [CrossRef]

Lackéus, Martin. 2013. Developing Entrepreneurial Competencies an Action-Based Approach and Classification in Entrepreneurial Education. Master's thesis, Chalmers University of Technology, Gothenburg, Sweden

Lackéus, Martin. 2014. An emotion based approach to assessing entrepreneurial education. The International Journal of Management Education 12: 374-96. [CrossRef] 
Lackéus, Martin. 2015. Entrepreneurship in Education: What, Why, When, How. Background Paper. Trento: OECD-LEED.

Lans, Thomas, Wim Hulsink, Herman Baert, and Martin Mulder. 2008. Entrepreneurship education and training in a small business context: Insights from the competence-based approach. Journal of Enterprising Culture 16: 363-83. [CrossRef]

Lans, Thomas, Vincent Blok, and Renate Wesselink. 2014. Learning apart and together: Towards an integrated competence framework for sustainable entrepreneurship in higher education. Journal of Cleaner Production 62: 37-47. [CrossRef]

Lans, Thomas, Vincent Blok, and Judith Gulikers. 2015. Show me your network and I'll tell you who you are: Social competence and social capital of early stage entrepreneurs. Entrepreneurship and Regional Development 27: 458-73. [CrossRef]

Lans, Thomas, Yvette Baggen, and Baggen Ploum. 2018. Towards more synergy in entrepreneurial competence research in entrepreneurship education. In A Research Agenda for Entrepreneurship Education. Edited by Alain Fayolle. Cheltenham: Elgar, pp. 224-42.

Larraín, Antonia. 2017. Argumentation and concept development: The role of imagination. European Journal of Psychology of Education 32: 521-36. [CrossRef]

Larson, Sheryl A., Robert Doljanac, Derek K. Nord, Patricia Salmi, Amy S. Hewitt, and Susan O'Nell. 2007. National Validation Study of Competencies for Frontline Supervisors and Direct Support Professionals. Minneapolis: University of Minnesota, Research and Training Center on Community Integration.

Lawson, Michael J., Stella Vosniadou, Penny Van Deur, Mirella Wyra, and David Jeffries. 2019. Teachers' and students' belief systems about the self-regulation of learning. Educational Psychology Review 31: 223-51. [CrossRef]

Le Deist, Françoise Delamare, and Jonathan Winterton. 2005. What is competence? Human Resource Development International 8: 27-46. [CrossRef]

López-Núñez, M. Inmaculada, Susana Rubio-Valdehita, Marta Evelia Aparicio-García, and Eva Díaz-Ramiro. 2020. Are entrepreneurs born or made? The influence of personality. Personality and Individual Differences 154: 109699. [CrossRef]

Man, Thomas Wing Yan. 2007. Understanding entrepreneurial learning. A competency approach. Entrepreneurship and Innovation 8: 189-98. [CrossRef]

Man, Thomas W. Y., Theresa Lau, and K. F. Chan. 2002. The competitiveness of small and medium enterprises: A conceptualization with focus on entrepreneurial competencies. Journal of Business Venturing 17: 123-42. [CrossRef]

Man, Thomas W. Y., Theresa Lau, and Ed Snape. 2008. Entrepreneurial competencies and the performance of small and medium enterprises: An investigation through a framework of competitiveness. Journal of Small Business E Entrepreneurship 21: 257-76. [CrossRef]

Martz, Ben, Jim Hughes, and Frank Braun. 2017. Creativity and problem-solving: Closing the skills gap. Journal of Computer Information Systems 57: 39-48. [CrossRef]

Mazzarol, Tim, Delwyn N. Clark, and Sophie Reboud. 2014. Strategy in action: Case studies of strategy, planning and innovation in Australian SMEs. Small Enterprise Research 21: 54-71. [CrossRef]

Meadows, Donella H. 2008. Thinking in Systems: A Primer. Hartford: Chelsea Green Publishing.

Mitchelmore, Siwan, and Jennifer Rowley. 2013. Growth and planning strategies within women-led SMEs. Management Decision 51: 83-96. [CrossRef]

Moore, Edel Mary. 2007. How to Kill Creativity-Ten Easy Steps. Industry and Higher Education 21: 337-43. [CrossRef]

Moore, Tim, and Janne Morton. 2017. The myth of job readiness? Written communication, employability, and the 'skills gap' in higher education. Studies in Higher Education 42: 591-609. [CrossRef]

Morris, Michael H., Justin W. Webb, Jun Fu, and Sujata Singhal. 2013. A competency-based perspective on entrepreneurship education: Conceptual and empirical insights. Journal of Small Business Management 51: 352-69. [CrossRef]

Muis, Krista R., Nesma Etoubashi, and Courtney A. Denton. 2020. The catcher in the lie: The role of emotions and epistemic judgments in changing students' misconceptions and attitudes in a post-truth era. Contemporary Educational Psychology 62: 101898. [CrossRef]

Mulder, Martin. 2014. Conceptions of professional competence. In International Handbook on Research into Professional and Practice-Based Learning. Dordrecht: Springer.

Mulder, Martin. 2015. Professional Competence in Context: A Conceptual Study. Wageningen: Wageningen University.

Mulder, Martin. 2017. Competence Based Vocational and Professional Education. Bridging the Worlds of Work and Education. Berlin and Heidelberg: Springer.

Mulder, Martin, Thomas Lans, Jos Verstegen, Harm Biemans, and Ypie Meijer. 2007. Competence development of entrepreneurs in innovative horticulture. Journal of Workplace Learning 19: 32-44. [CrossRef]

Mulder, Martin, Judith Gulikers, Harm Biemans, and Renate Wesselink. 2009. The new competence concept in higher education: Error or enrichment? Journal of European Industrial Training 33: 755-70. [CrossRef]

Murphy, Mary C., and Carol S. Dweck. 2010. A culture of genius: How an organization's lay theory shapes people's cognition, affect, and behavior. Personality and Social Psychology Bulletin 36: 283-96. [CrossRef] [PubMed]

Ernest Samwel Mwasalwiba. 2010. Entrepreneurship education: A review of its objectives, teaching methods, and impact indicators. Education + Training 52: 20-47. [CrossRef]

Nabi, Ghulam R. 2003. Graduate employment and underemployment: Opportunity for skills use and career experiences amongst recent business graduates. Education + Training 45: 371-82. [CrossRef] 
Nägele, Christof, and Barbara E. Stalder. 2017. Competence and the need for transferable skills. In Competence-Based Vocational and Professional Education. Technical and Vocational Education and Training: Issues, Concerns and Prospects. Edited by Martin Mulder. Berlin and Heidelberg: Springer, vol. 23, pp. 739-53. [CrossRef]

Neck, Heidi M., and Andrew C. Corbett. 2018. The Scholarship of Teaching and Learning Entrepreneurship. Entrepreneurship Education and Pedagogy 1: 8-41. [CrossRef]

Neck, Heidi M., and Patricia G. Greene. 2011. Entrepreneurship education: Known worlds and new frontiers. Journal of Small Business Management 49: 55-70. [CrossRef]

Novak, Joseph D. 2002. Meaningful learning: The essential factor for conceptual change in limited or inappropriate propositional hierarchies leading to empowerment of learners. Science Education 86: 548-71. [CrossRef]

OECD. 2016. Preparing Our Youth for An Inclusive and Sustainable World. The OECD PISA Global Competence Framework. Available online: https://www.oecd.org/education/Global-competency-for-an-inclusive-world.pdf (accessed on 1 September 2021).

OECD. 2018. The Future of Education and Skills. Education 2030. Paris: OECD Publishing. Available online: http://www.oecd.org/ education/2030/E2030\%20Position\%20Paper\%20(05.04.2018).pdf (accessed on 1 September 2021).

OECD. 2019. Future of Education and Skills 2030 Conceptual Learning Framework. Transformative Competencies for 2030. Paris: OECD Publishing. Available online: www.oecd.org/education/2030-project/learning/transformative-competencies (accessed on 1 September 2021).

Omrane, Amina, Amal Kammoun, and Claire Seaman. 2018. Entrepreneurial Burnout: Causes, Consequences and Way Out. FIIB Business Review 7: 28-42. [CrossRef]

O'Neil, Harold F., Jr. 2014. Workforce Readiness Competencies and Assessment. New York and London: Psychology Press under Taylor and Francis Group.

Onstenk, Jeroen. 2003. Entrepreneurship and Vocational Education. European Educational Research Journal 2: 74-89. [CrossRef]

Patzelt, Holger, and Dean A. Shepherd. 2011. Recognizing opportunities for sustainable development. Entrepreneurship Theory and Practice 35: 631-52. [CrossRef]

Pita, Mariana, Joana Costa, and António Carrizo Moreira. 2021. Entrepreneurial ecosystems and entrepreneurial initiative: Building a multi-country taxonomy. Sustainability 13: 4065. [CrossRef]

Pittaway, Luke, Elena Rodriguez-Falcon, Olaojo Aiyegbayo, and Amanda King. 2010. The role of entrepreneurship clubs and societies in entrepreneurial learning. International Small Business Journal 29: 37-57. [CrossRef]

Rae, David. 2003. Opportunity centred learning: An innovation in enterprise education? Education + Training 45: 542-49. [CrossRef]

Ranney, Michael Andrew, and Dav Clark. 2016. Climate change conceptual change: Scientific information can transform attitudes. Topics in Cognitive Science 8: 49-75. [CrossRef] [PubMed]

Rasmussen, Anders, and Anne Fritzmer. 2016. From Dream to Reality: Learning Outcomes and Didactic Principles for Teaching Entrepreneurship in Nordic Schools. Copenhagen: Nordic Council of Ministers.

Rasmussen, A., and N. Nybye. 2013. Entrepreneurship Education: Progression Model. Odense: The Danish Foundation for Entrepreneurship-Young Enterprise.

Rasmussen, Anders, Kåre Moberg, and Christine Revsbech Jensen. 2015. A Taxonomy of Entrepreneurship Education: Perspectives on Goals, Teaching and Evaluation. Odense: The Danish Foundation for Entrepreneurship-Young Enterprise.

Reeve, Johnmarshall. 2009. Why teachers adopt a controlling motivating style toward students and how they can become more autonomy supportive. Educational Psychologist 44: 159-75. [CrossRef]

Reynolds, Sue, Bernadette Welch, and Mary Carroll. 2012. Passionate practitioners: Engaging not just the head but also the heart. Education for Information 29: 243-51. [CrossRef]

Ryan, Richard M., and Edward L. Deci. 2017. Self-Determination Theory: Basic Psychological Needs in Motivation, Development, and Wellness. New York and London: Guilford Publications.

Rychen, Dominique S., and Laura H. Salganik, eds. 2003. Key Competencies for a Successful Life and Well-Functioning Society. Gottingen: Hogrefe and Huber.

Salas, Eduardo, Nancy J. Cooke, and Michael A. Rosen. 2008. On teams, teamwork, and team performance: Discoveries and developments. The Journal of the Human Factors and Ergonomics Society 50: 540-47. [CrossRef]

Sarasvathy, Saras D., and Sankaran Venkataraman. 2011. Entrepreneurship as method: Open questions for an entrepreneurial future. Entrepreneurship Theory and Practice 35: 113-35. [CrossRef]

Sánchez, José C. 2011. University training for entrepreneurial competencies: Its impact on intention of venture creation. International Entrepreneurhip Management Journal 7: 239-54. [CrossRef]

Shane, Scott Andrew. 2003. A General Theory of Entrepreneurship: The Individual-Opportunity Nexus. Cheltenham: Edward Elgar.

Shane, Scott, and Sankaran Venkataraman. 2000. The promise of entrepreneurship as a field of research. The Academy of Management Review 25: 217-26. [CrossRef]

Sinatra, Gale M. 2005. The "warming trend" in conceptual change research: The legacy of Paul R. Pintrich. Educational Psychologist 40: 107-15. [CrossRef]

Sinatra, Gale M., and Gita Taasoobshirazi. 2018. The self-regulation of learning and conceptual change in science: Research, theory, and educational applications. In Handbook of Self-Regulation of Learning and Performance. Edited by Dale H. Schunk and Barry Zimmerman. Washington, DC: Routledge, Taylor \& Francis Group, pp. 153-65. 
Stewart, Jim, and Vanessa Knowles. 2000. Graduate recruitment and selection practices in small businesses. Career Development International 5: 21-38. [CrossRef]

Steyaert, Chris. 2007. 'Entrepreneuring' as a conceptual attractor? A review of process theories in 20 years of entrepreneurship studies. Entrepreneurship E Regional Development: An International Journal 19: 453-77. [CrossRef]

Stoof, Angela. 2005. Tools for the Identification and Description of Competencies. Master's thesis, Open University of Netherland, Heerlen, The Netherlands.

Strauss, Karoline, and Sharon K. Parker. 2014. Effective and sustained proactivity in the workplace: A self-determination theory perspective. In The Oxford Handbook of Work Engagement, Motivation, and Self-Determination Theory. Oxford: Oxford University Press, pp. 50-71.

Tambe, Milind. 1997. Towards flexible teamwork. Journal of Artificial Intelligence Research 7: 83-124. [CrossRef]

Thomas, Michael S. C., Denis Mareschal, and Iroise Dumontheil, eds. 2020. Educational Neuroscience: Development Across the Life Span. New York: Routledge.

Audretsch, David B., Martin A. Carree, Roy Thurik, and Andre J. van Stel. 2008. Does self-employment reduce unemployment? Journal of Business Venturing 23: 673-86. [CrossRef]

Toutain, Olivier, and Alain Fayolle. 2017. Labour Market Uncertainty and Career Perspectives: Competence in Entrepreneurship Courses. In Competence-Based Vocational and Professional Education. Technical and Vocational Education and Training: Issues, Concerns and Prospects. Edited by Martin Mulder. Berlin and Heidelberg: Springer, vol. 23, pp. 985-1005.

Tynjälä, Päivi. 1999. Towards expert knowledge? A comparison between a constructivist and a traditional learning environment in the university. International Journal of Educational Research 31: 357-442. [CrossRef]

Tynjälä, Päivi. 2016. Ajatteluun kehitys aikuisuudessa-Kohti moninäkökulmaisuuta. In Suomen Kasvatustieteen Seuraa ry, Kasvatusalan Tutkimuksia. Edited by Eeva Kallio. Jyväskylä: Suomen Kasvatustieteellinen Seura, pp. 227-44.

Ucbasaran, Deniz, Paul Westhead, and Mike Wright. 2008. Opportunity identification and pursuit: Does an entrepreneur's human capital matter? Small Business Economics 30: 153-73. [CrossRef]

UK Commission for Employment and Skills. 2009. The Employability Challenge. Full Report. London: UKSES.

U.S. Department of Labor. 2019. U.S. Department of Labor, Employment \& Training Administration. Competency ModelsCommunicating Industry's Education and Training Needs. Competency Model Development and Use-A Technical Assistance Guide. Available online: http:/ / docplayer.net/15205131-competency-models-communicating-industry-s-education-andtraining-needs-competency-model-development-and-use-a-technical-assistance-guide.html (accessed on 1 September 2021).

Vaidya, Shipra. 2014. Developing Entrepreneurial Life Skills. Berlin and Heidelberg: Springer, p. 15. [CrossRef]

Venesaar, Urve, Marge Täks, Grete Arro, Elina Malleus, Krista Loogma, Kaja Mädamürk, Eneken Titov, and Martin Toding. 2018. Ettevõtluspädevuse mudeli empiiriline põhjendamine ettevõtlusõppe arendamise alusena. (Model of entrepreneurship competence as a basis for the development of entrepreneurship education). Eesti Haridusteaduste Ajakiri (Estonian Journal of Education) 6: 118-55. [CrossRef]

Vestergaard, Lene, Kåre Moberg, and Casper Jørgensen. 2012. Impact of Entrepreneurship Education in Denmark-2011. Odense: The Danish Foundation for Entrepreneurship-Young Enterprise. Available online: http://eng.ffe-ye.dk/media/202248/impact_of_ entrepreneurship_education_in_denmark_2011.pdf (accessed on 1 September 2021).

Virtanen, Anne, and Päivi Tynjälä. 2019. Factors explaining the learning of generic skills: A study of university students' experiences. Teaching in Higher Education 24: 880-94. [CrossRef]

Vogel, Peter. 2017. From Venture Idea to Venture Opportunity. Entrepreneurship Theory and Practice 41: 1-27. [CrossRef]

von Bertalanffy, Ludwig. 1968. General System Theory: Essays on Its Foundation and Development. New York: George Braziller.

Vorhauser-Smith, Sylvia. 2013. How the Best Places to Work Are Nailing Employee Engagement. Forbes. Available online: http://www. forbes.com/sites/sylviavorhauser-smith/2013/08/14/how-the-best-places-to-work-are-nailing-employee-engagement/ (accessed on 1 September 2021).

Vosniadou, Stella. 2007. Conceptual change and education. Human Development 50: 47-54. [CrossRef]

Vygotsky, Lev. 1978. Interaction between learning and development. In Mind and Society. Cambridge: Harvard University Press, pp. 79-91.

Vygotsky, Lev S. 1986. Thought and Language. Edited by Alex Kozulin. Cambridge: MIT Press.

Wei, Xueyan, Shuangxin Cang, and Robert D. Hisrich. 2015. Entrepreneurial stressors as predictors of entrepreneurial burnout. Psychological Reports 116: 74-88. [CrossRef]

Winterton, Jonathan, Françoise Delamare Le Deist, and Emma Stringfellow. 2006. Typology of Knowledge, Skills and Competences: Clarification of the Concept and Prototype. Luxembourg: Office for Official Publications of the European Communities.

Yeager, David Scott, and Carol S. Dweck. 2012. Mindsets that promote resilience: When students believe that personal characteristics can be developed. Educational Psychologist 47: 302-14. [CrossRef] 